\title{
HYNKOVICE - NEZNÁMÁ ZANIKLÁ STŘEDOVĚKÁ VES V ORLICKÝCH HORÁCH
}

\author{
MOJMÍR REŽNÝ - DAVID VÍCH
}

\begin{abstract}
Abstrakt: V letech 2009-2014 došlo k objevu a povrchovému pruzkumu dosud neznámé zaniklé středověké vesnice v Orlických horách, kterou ústni tradice označuje jako Hynkovice. Vesnice vznikla dle získaných movitých nálezù, při absenci písemných zpráv, někdy okolo prelomu 13. a 14. století, zanikla nejpozději ve staršim úseku 15. století. Př́činy vzniku vsi ve značné nadmořské výšce (okolo $670 \mathrm{~m}$ ) neznáme, hornická činnost doložena není. Sídliště je důležitým indikátorem přitomnosti člověka v krajině dle výpovědi písemných pramenů osidlené spolehlivě až počátkem 16. století.
\end{abstract}

Klíčová slova: zaniklá ves - vrcholný středověk - Orlické hory-východní Čechy.

\section{Hynkovice: A Defunct Medieval Village Discovered in the Orlické Hory Mountains}

Abstract: A defunct medieval village was discovered and investigated with surface prospection in the Orlicke hory mountains in 2009-2014. Oral tradition refers to the village as Hynkovice. No written records have survived; however, material finds indicate that the village came into existence in the late 13th or the early 14th century and ceased to exist at the end of the 15th century at the latest. The reasons for the establishment of the village situated relatively high (670 $\mathrm{m}$ above sea level) are unknown, mining activities were not confirmed. The settlement is an important indicator of the presence of man in the landscape settled, according to written sources, as late as the early 16th century.

Key words: defunct village - high Middle Ages - Orlické hory mountains - east Bohemia.

\section{1 Úvod}

V roce 2009 došlo na rozhraní k. ú. Jamné nad Orlicí a Těchonín (okr. Ústí nad Orlicí, Pardubický kraj) v Orlických horách k objevu dosud neznámé zaniklé stř̌edověké vsi. Výsledky průzkumu jsou předmětem následujících řádků.

\section{Lokalizace a př́rodní podmínky}

První relikty zaniklé vsi byly po delší době neúspěšného pátrání lokalizovány v roce 2009 s postupným objevováním dalších pozůstatků v následujících letech. Relikty jednotlivých usedlostí vsi byly zjištěny v lučním údolí a přilehlém lesním terénu nad Černovickým potokem pod vrchem Javorně (popř. také Javorna, Javoryna, $781 \mathrm{~m}$ n.m., obr. 1), v nadmořské výšce okolo $670 \mathrm{~m}$. Poloha zaniklé vsi je na ZM ČR 1: 10000 , list 14-14-25, vymezena body $40 \mathrm{~mm}$ od Z s. č. a $5 \mathrm{~mm}$ od J s. č. Vesnice leží svojí západní částí v katastrálním území Těchonína, východní část vsi již zasahuje do katastrálního území Jamné nad Orlicí.

Z pozůstatků zaniklé jednořadé vsi identifikoval jeden z autorů (Mojmír Režný) devět reliktů, pracovně (a zcela jistě nepřesně) označených jako usedlosti, jež jsou od sebe vzdáleny 60-80 m (obr. 2). Západní část vsi (usedlosti č. 2-6) je situována do zalesněného svažitého terénu nad Černovickým potokem a zpevněnou lesní cestou z Těchonína na Suchý vrch $(995 \mathrm{~m}$ n.m.), relikty usedlostí č. 1 a 7 leží již na louce nedaleko hájovny Zakopanka. Tzv. usedlost 8 se nachází na louce již v k. ú. Jamné nad Orlicí. Za zmínku stojí i dodnes zřetelné stopy po zaniklé cestě $\mathrm{s}$ torzem nasypaného terénu pro můstek přes prrilehlý potok.

\section{Metodika průzkumu}

Hlavním úkolem v první fázi průzkumu byla verifikace ústní tradice hovořící o přítomnosti zaniklé středověké vsi Hynkovice někde v okolí hájovny Zakopanka (obr. 3) s využitím metodiky vypracované Ervínem Černým (1979). Průzkum se v této fázi zaměřil na nadzemní terénní relikty. 


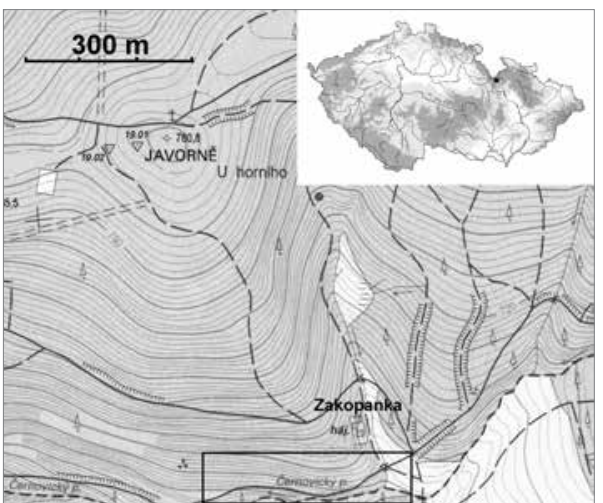

Obr. 1. Hynkovice. Vyznačení jádra vesnice s usedlostmi č. 1-7, 9 na výřezu mapy $1: 10000$.

Abb. 1. Hynkovice. Gekennzeichneter Kern des Dorfes mit Anwesen Nr. 1-7, 9 auf einem Kartenausschnitt $1: 10000$.
Rozpoznávání jednotlivých usedlostí komplikovalo silné narušení terénu starými vývraty, což na jedné straně vedlo k setření reliktů skutečných, na straně druhé k vytváření ,pseudoreliktů " připomínajících svým tvarem pozůstatky zaniklé vsi. Kritériem pro identifikaci antropogenních pozůstatků byla přítomnost movitých nálezů, především keramiky a popř. mazanice, získaných mikrovrypy.

V letech 2011-2012 proběhlo několik individuálních orientačních průzkumů $\mathrm{s}$ detektorem kovů (zpočátku byly prováděny objevitelem lokality s lokalizací pouze na jednotlivé usedlosti bez zaměřování, později se zaměřováním ruční stanicí GPS Garmin Oregon 550, obr. 4), které prokázaly značný potenciál lokality ohledně výskytu kovových artefaktů. Dle všech známek zůstala lokalita stranou pozornosti nelegálních uživatelů de-

tektorů kovů, což doložili také obyvatelé nedaleké hájovny, kteří zde bydlí celoročně. Vzhledem k tomuto zjištění a vysoké pravděpodobnosti výskytu intaktních archeologických situací (byt' těžce narušených erozí a dalšími postdepozičními procesy) bylo od dalšího detektorového průzkumu upuštěno do doby, než se podaří zajistit finanční prostředky na geodetické zaměření jednotlivých předmětů spojené s pořízením geodetického plánu celé lokality.

Dne 26. 4. 2014 proběhl detektorový průzkum celé lokality za pomoci spolupracovníků Regionálního muzea ve Vysokém Mýtě. Místa, odkud byly vyjímány kovové předměty, jsme označovali očíslovanými kolíky, identická čísla byla přidělována vyzvedávaným předmětům. V návaznosti na detektorový průzkum proběhlo geodetické zaměření bodů a jednotlivých usedlostí (obr. 5). Geodetické zaměření provedla Zeměměřičská kancelář Kostelec nad Orlicí, a to díky

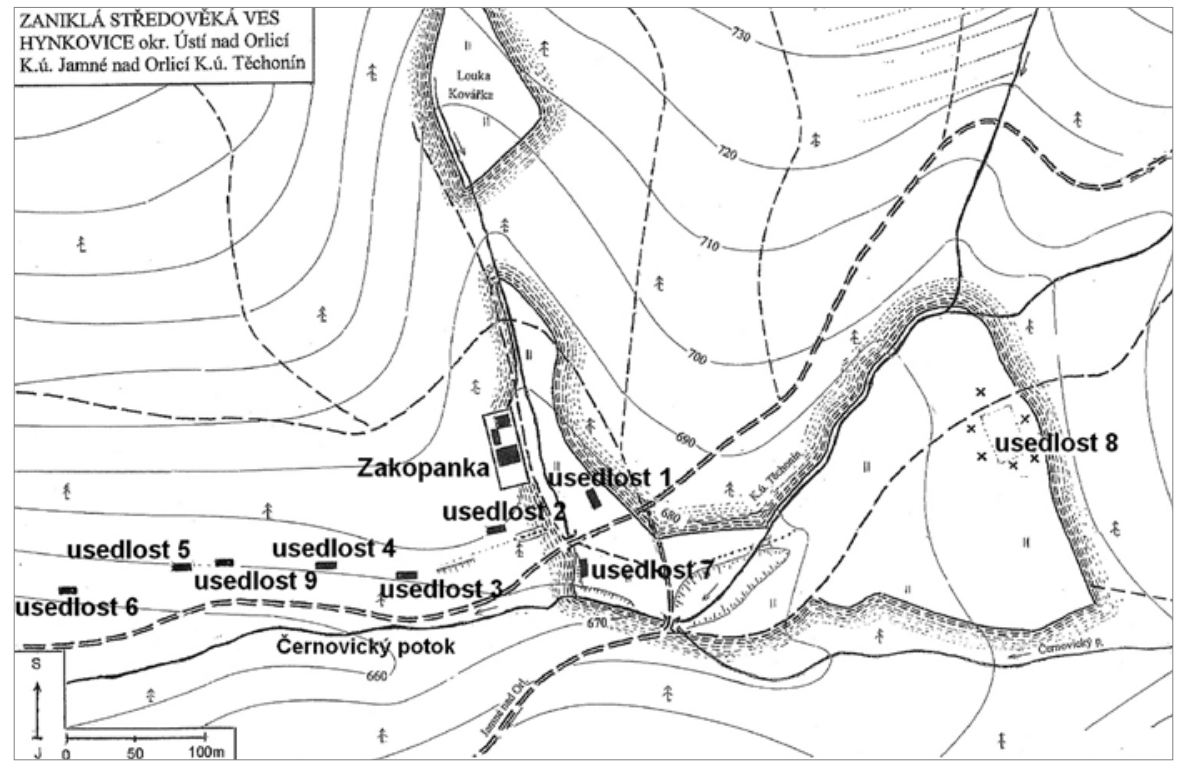

Obr. 2. Hynkovice. Pracovní plán lokality s vynesenými usedlostmi č. 1-9.

Abb. 2. Hynkovice. Arbeitsplanskizze der Fundstelle mit eingetragenen Anwesen Nr. 1-9. 


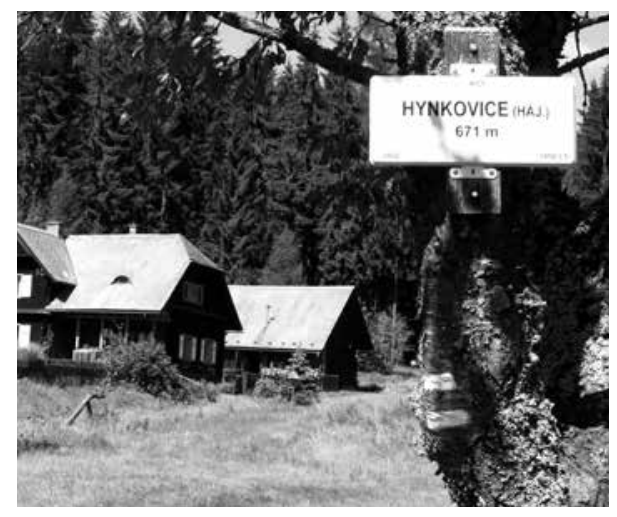

Obr. 3. Těchonín, poloha s pomístním názvem Hynkovice. V pozadí hájovna Zakopanka. Foto D. Vích.

Abb. 3. Těchonín, Lage mit dem Flurnamen Hynkovice. Im Hintergrund das Forsthaus Zakopanka. Foto D. Vích. pochopení Obce Těchonín, která na zaměření poskytla finanční prostředky. Jednotlivé vkopy jsme pojímali jako mikrovrypy s popisem jednotlivých stratigrafických jednotek a oddělenou separací movitých nálezů. Mikrovrypy jsme vedle geodetického zaměření pro jistotu zaměřovali duplicitně ruční stanicí GPS. Informace o nálezech zaměřených ruční stanicí GPS jsme zanesli do tabulky Microsoft Excel s průběžným číslováním jednotlivých artefaktů. Pod těmito čísly pak kovové předměty figurují v katalogové části práce a $\mathrm{v}$ př́íslušných plánech.

\section{Písemné prameny}

K lokalitě postrádáme jakékoliv zprávy v písemných pramenech. O zaniklé středověké vsi (dále ZSV) podávají informace (vedle archeologických nálezů) výhradně zprávy předávané jamenskými obyvateli z pokolení na pokolení ústní tradicí, fixovanou písemně až v kronice Jamného nad Orlicí z roku 1926:

„Dle staré tradice stávala prý nahoře v lesich osada lesní, jak někteři míni ,U nových pasek', jiní zase pod Suchým vrchem ,U korýtek', ač mínění ono považováno jest za báji (...). Zde asi mezi lety 1230-1250 vystavěl si nějaký Hynek Drslav, ze kterého rodu je těžko řici, ježto $v$ této době nebyla ani rodinná jména pánů ustálená a synové téhož otce dávali si různá jména dle hradĩ a osad, své sídlo. Po něm nazvána asi tato část osady Hynkov.“

Na jiném místě čteme: „Jak již řečeno vystavěl si pan Hynek pro dobu lovu zámeček, $v$ němž bydlel lovčí, a chaty pro hajné. Dále byla tu ovčárna, krčma a několik uhliřských chat, jež tvořily osadu zvanou Hynkov. Ježto však neměla př́znivých podminek k rozšírení zemédělství, záhy asi zanikla a jen opálené kameny a zbytky hliněných nádob nasvědčují tomu, že tam lidé žili. Ještě pred 70 lety znaly ženy chodici do lesa na trávu misto ,Krchovíček' zvané, kam chodivaly na píci. Snad si dotyčný pán přvedl sebou některé osadníky, ježto nemajice v těchto mistech príhodných podminek, v části horního Jamného se usadili.“

Bez problémů není ani výpověd' písemných pramenů k osídlování horního toku Tiché Orlice, přičemž osídlovací proces postupoval podél této řeky proti jejímu proudu. Za organizátory kolonizace tohoto území jsou považováni především páni z Kyšperka (dnešní Letohrad). Ovšem i v těchto širších souvislostech se potýkáme s problémem nejednoznačné výpovědi písemných pramenů. Obce Těchonín a Jamné nad Orlicí, na jejichž katastrálním území se dnes Hynkovice nachází, poprvé spolehlivě vstupují do písemných pramenů rokem 1514 (Těchonín) a rokem 1409 (Jamné nad Orlicí), přičemž zatím zůstává nerozřešenou otázkou, zda obě obce neměly starší předchůdce pod označením Ludmirsdorf a Perchtolsdorf, oba doložené již k roku 1304, jako důsledek kolonizace levého břehu Tiché Orlice pány z Drnholce (Musil 2002, 60-61, 174-176).

\section{Popis situace}

\subsection{Usedlosti}

Usedlost č. 1 (ve všech případech zaměřeno ruční stanicí Garmin OREGON 550, WGS 84, UTM; E 0618670, N 5545621)

Identifikována byla jako první v záŕí roku 2009 na louce nedaleko hájovny Zakopanka a zahajuje řadu usedlostí objevenou na pravém břehu Černovického potoka. Jeví se jako plošina o rozměrech

1 František Grus, Kronika obce Jamné nad Orlici, založená roku 1926 (rukopis kroniky uložen na Obecním úřadě v Jamném nad Orlicí), s. 46. 


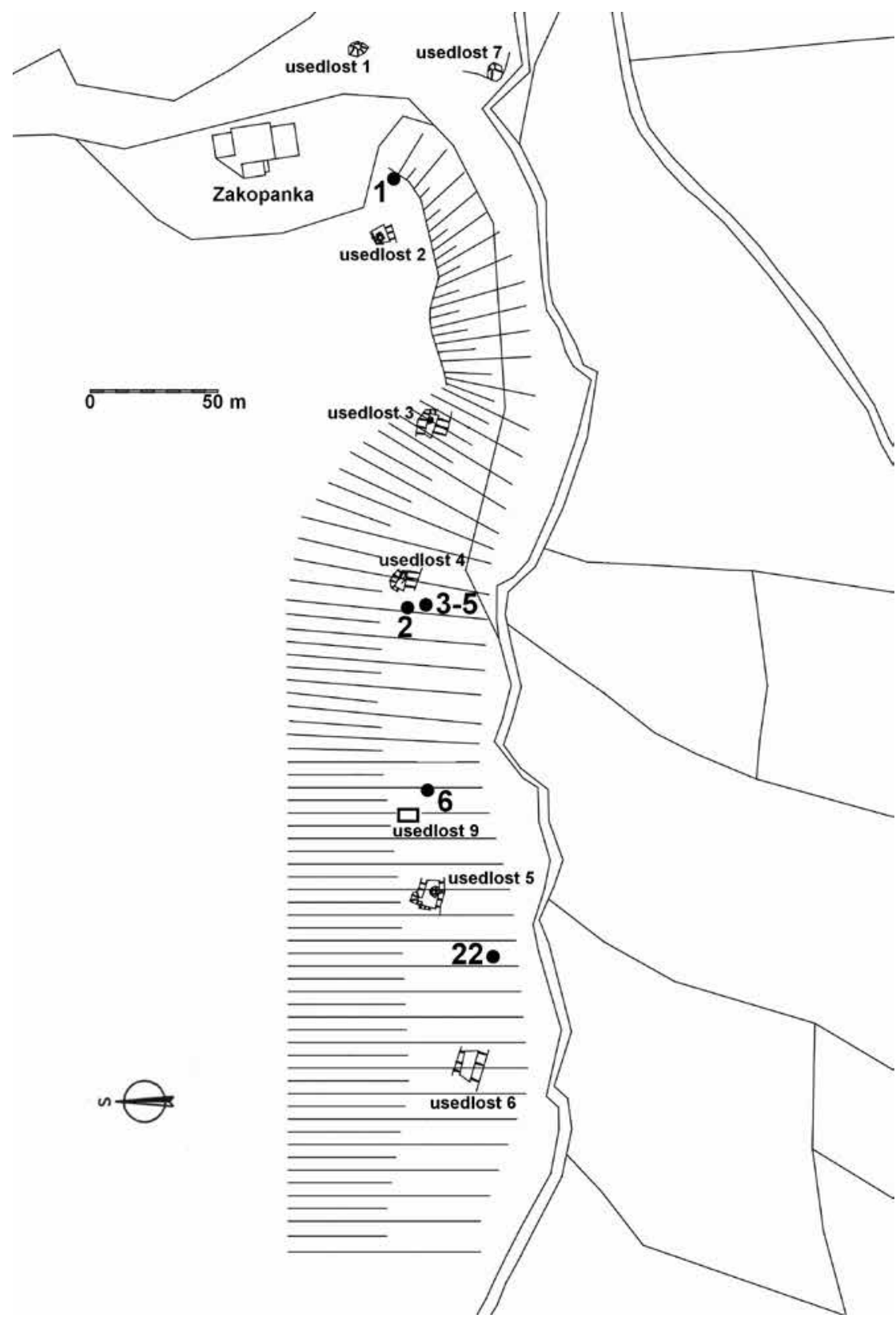

Obr. 4. Geodetické zaměření Hynkovic s vynesením kovových nálezů zaměřených pouze ruční stanicí GPS (číslování odpovídá číslování v katalogové části, č. 44 mimo mapový výřez západně od zaniklé vsi).

Abb. 4. Geodätische Vermessung von Hynkovice mit eingetragenen, nur mit GPS-Handstation vermessenen Metallfunden (die Nummerierung entspricht der Nummerierung im Katalogteil, Nr. 44 außerhalb des Kartenausschnitts westlich der Dorfwüstung). 


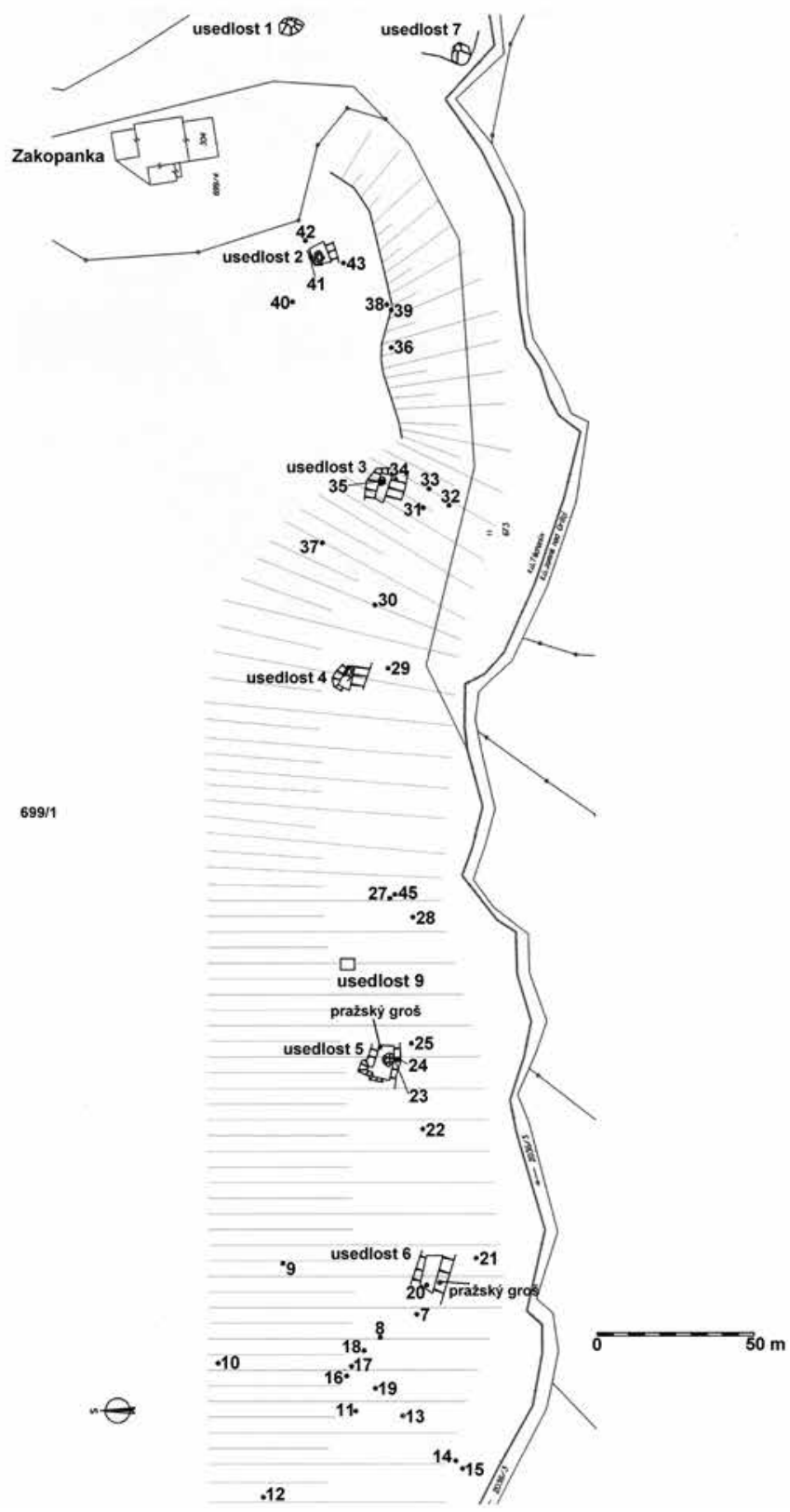

Obr. 5. Geodetické zaměření Hynkovic s geodeticky zaměřenými místy nálezů (číslování odpovídá číslování v katalogové části).

Abb. 5. Geodätische Vermessung von Hynkovice mit geodätische vermessenen Fundorten (die Nummerierung entspricht der Nummerierung im Katalogteil). 
přibližně $6,5 \times 6 \times 7 \times 6,5 \mathrm{~m}$ se slabě patrnou vyvýšeninou o výšce ca $0,4 \mathrm{~m}$ v mírném svažitém terénu těsně nad zamokřenou částí louky s protékající malou vodotečí (obr. 6). Plošina zvolna přechází v okolní terén.

Usedlost č. 2 (E 0618542, N 5545583)

Usedlost č. 2 se podařilo zjistit $\mathrm{v}$ červnu roku 2010 teprve po mnoha neúspěšných pokusech v lesní části nad loukou s usedlostí č. 1. Poměrně špatně „čitelná“ plocha půdorysu usedlosti o rozměrech $6 \times 6 \times 6 \times 7 \mathrm{~m}$ je zaříznuta do mírně svažitého terénu, uprostřed se nachází nakupenina lomového kamene o rozměrech 3,5 × 2,7 a výšce $0,4 \mathrm{~m}$ (obr. 6).

Usedlost č. 3 (E 0618513, N 5545572)

Usedlost objevenou v ř́innu roku 2010 spolu s usedlostmi č. 4, 5, 6 tvoří dobře patrná plošina o rozměrech $5 \times 12 \times 12 \times 4,5 \mathrm{~m}$, přičemž do rozměru plošiny se nepochybně promítla erozní činnost. Dobře patrná kupole tvořená kamennou destrukcí o rozměrech $3,8 \times 2,7 \mathrm{~m}$ dosahuje výšky $0,4 \mathrm{~m}$ a je situována do východní části plošiny (obr. 6).

Usedlost č. 4 (E 0618448, N 5545578)

Nejlépe dochovanou usedlost tvoří plošina o rozměrech $7 \times 5 \times 7,5 \times 8 \mathrm{~m}$ zasazená do výrazného svahu. O vlivu eroze svědčí kupole o rozměrech $4,8 \times 3,4 \mathrm{~m}$ a výšce $0,4 \mathrm{~m} \mathrm{z}$ kamenné destrukce posazená na samé jižní hraně plošiny a splachové vrstvy s movitými nálezy zjištěné pod plošinou (obr. 6).

\section{Usedlost č. 5 (E 0618340, N 5545547)}

Plošinu usedlosti o rozměrech 7,5 × $11 \times 5,5 \times 11,5 \mathrm{~m}$ zasazenou do svahu velmi negativně poznamenala činnost vývratů. U této usedlosti jako jediné byl v západní části při severní straně zaznamenán „výklenek“ o rozměrech $2,5 \times 2 \mathrm{~m}$ představující snad relikt propadlého sklípku. Kamenná destrukce v podobě kupole o rozměrech $4,5 \times 3,8 \mathrm{~m}$ dosahovala výšky $0,3 \mathrm{~m}$. Také zde jižní část reliktu výrazně poznamenala eroze (obr. 6).

Usedlost č. 6 (E 0618270, N 5545535)

Plošina o rozměrech $11 \times 5 \times 13 \times 5,5 \mathrm{~m}$ jako jediná postrádá kamennou kupolovitou destrukci (obr. 6). Vzhledem ke zjištěné terénní situaci mohlo k zániku destrukce dojít až druhotně vlivem pohybu těžké lesní techniky.

\section{Usedlost č. 7 (E 0618663, N 5545569)}

Zachovala se jako slabě patrný pahorek (výška ca $40 \mathrm{~cm}$ ) na soutoku Černovického potoka a jeho bezejmenného přítoku. Usedlost je situována na břehu při jeho samé hraně a narušuje ji eroze, což dokládá keramika sebraná pod břehem (obr. 6).

Tzv. usedlost č. 8 (E 0618978, N 5545706)

Takto pracovně jsme nazvali jedinou mikrovrypy zjištěnou kumulaci keramiky na ploché louce bez jakýchkoliv terénních reliktů. O charakteru lidských aktivit by mohl prozradit více pouze archeologický výzkum. Vzhledem k absenci jakýchkoliv terénních prŕznaků byl objekt zaměřen pouze ruční stanicí GPS, nikoliv geodeticky. 


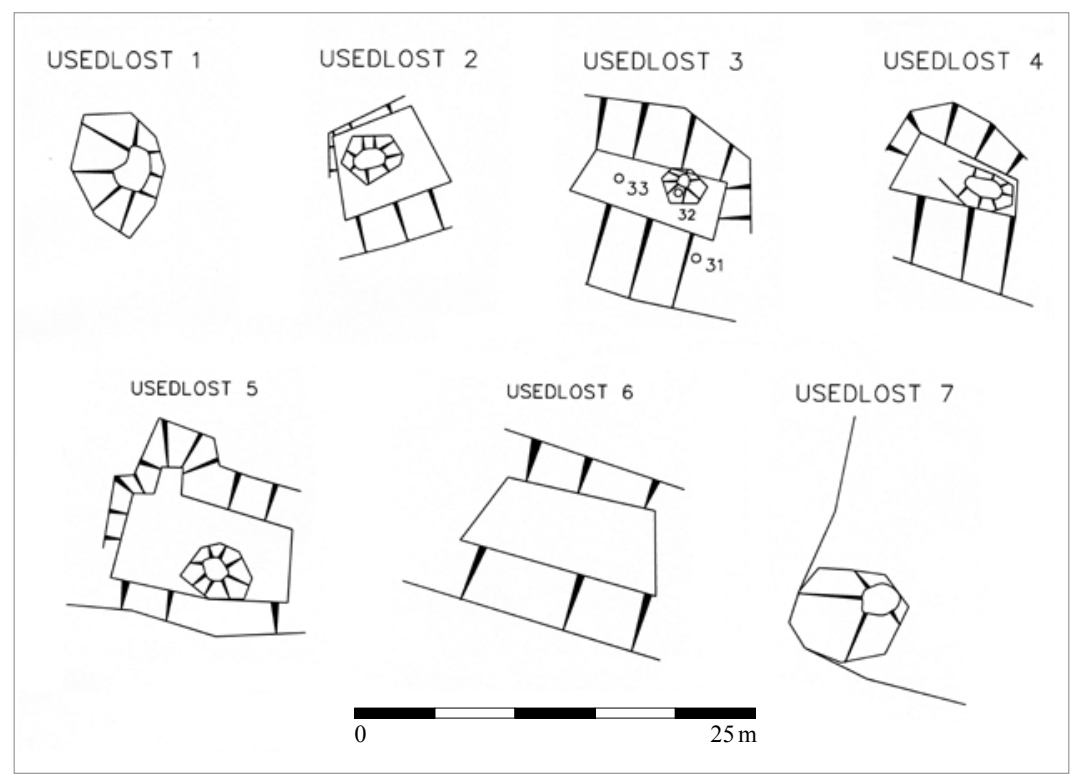

Obr. 6. Hynkovice. Detail usedlostí č. 1-7.

Abb. 6. Hynkovice. Anwesen Nr. 1-7 im Detail.

Tzv. usedlost č. 9 (E 0618375, N 5545570)

„Neklidný terén“ v podobě několika vyvýšenin nerozpoznatelných od vývratů přinesl několik kovových artefaktů a při mikrovrypech i kolekci keramiky. Vzhledem k blízkosti usedlosti č. 5 se spíše jedná o hospodářský objekt $\mathrm{s}$ usedlostí č. 5 související, což potvrzuje i nález žárem poznamenaného brusného kamene. Vzhledem k absenci spolehlivých terénních příznaků byl objekt zaměřen pouze ruční stanicí GPS, nikoliv geodeticky.

Dle terénních reliktů v podobě do svahu vtesaných plošin tvořících řadu (analogicky např. zaniklý Hamlíkov - Černý 1992, 28-29; Schwarzenbach - Klír-Kenzler 2009, 660), na nichž jednotlivé usedlosti stály, a dle absence většího objemu kamenné destrukce domy obyvatel Hynkovic byly dřevěné konstrukce, patrně s kamennou podezdívkou. Kupole tvořené lomovým kamenem interpretujeme jako pozůstatky otopných zařízení - pecí, pravdivost této hypotézy (i s ohledem k absenci mazanice) však může potvrdit pouze archeologický výzkum. O prostorovém uspořádání jednotlivých usedlostí ani dalších stavbách hospodářského charakteru nejsme bez archeologického výzkumu schopni říci nic. Usedlosti stály v řadě podél pravého břehu Černovického potoka.

\subsection{Plužiny}

Plužiny nezbytné pro obživu obyvatel Hynkovic se nedochovaly, terén však v zásadě vylučuje jejich situování do prostoru za usedlostmi. Můžeme je předpokládat především v prostoru louky při hájovně. Mimo ni jsme lokalizovali torzovité stopy po mezních pásech s hromádkami do řad sesbíraného kamení v lesním prostoru severovýchodně od hájovny Zakopanka. Místo dodnes pamětníci nazývají Kopaniny. Odtud se stopy po polích táhnou směrem k louce Kovářce (obr. 7). 
Za pozůstatky osídlení Hynkovic lze snad považovat i přítomnost několika menších, dnes již zalesněných lučních enkláv, které jsou zaznamenány na mapách stabilního katastru z let 1839 a 1840, stejně jako na druhém vojenském mapování z let 1852-1853. Louka známá dodnes jako Horáčkův brant a zejména 350 m východně vzdálená zalesněná louka nad Černovickým potokem nesou stopy po dávné lidské činnosti (znovu se opakující hromady kamení). Terénní prospekcí tu byla získána mladší keramika ze 17. a 18. století (především torzo keramické trojnožky se zelenou glazurou, která je barokního stáŕí). Nechybějí tu ani pozůstatky novodobého osídlení. Jde o zbytky základů lovecké chaty s přilehlým malým rybníčkem, snad někdy z počátku 20. století.

\section{Movité nálezy}

Dochované terénní relikty uchovávající movité archeologické nálezy jsou jedinými prameny umožňujícími nahlédnout do dějin zaniklé osady. Artefakty v podobě keramiky a kovových předmětů byly získány v průběhu provádění mikrovrypů, kterými jsme verifikovali př́tomnost jednotlivých usedlostí, a detektorovým průzkumem.

\subsection{Keramika}

Z areálu ZSV Hynkovice disponujeme celkem 266 ks zlomky vrcholně středověké keramiky a 12 ks keramiky novověké. Soubor jsme získali především při mikrovrypech v rámci jednotlivých usedlostí při snaze o verifikaci nadzemních reliktů. Nevelká kolekce pochází z detektorového průzkumu - keramické zlomky byly zjištovány a samostatně separovány při vkopech pro kovové předměty.

Soubor tvoří přibližně ve stejném poměru redukčně pálená keramika šedavých odstínů a keramika s oxidačním výpalem $\mathrm{v}$ odstínech červené. $\mathrm{V}$ obou skupinách se vedle písčitého ostřiva stále ještě objevuje i ostření slídou. Povrch je opatřen rytou šroubovicí, častěji se však objeví šroubovice vývalková. Samostatnou skupinu tvoří světlý plavený střep opatřený výval-

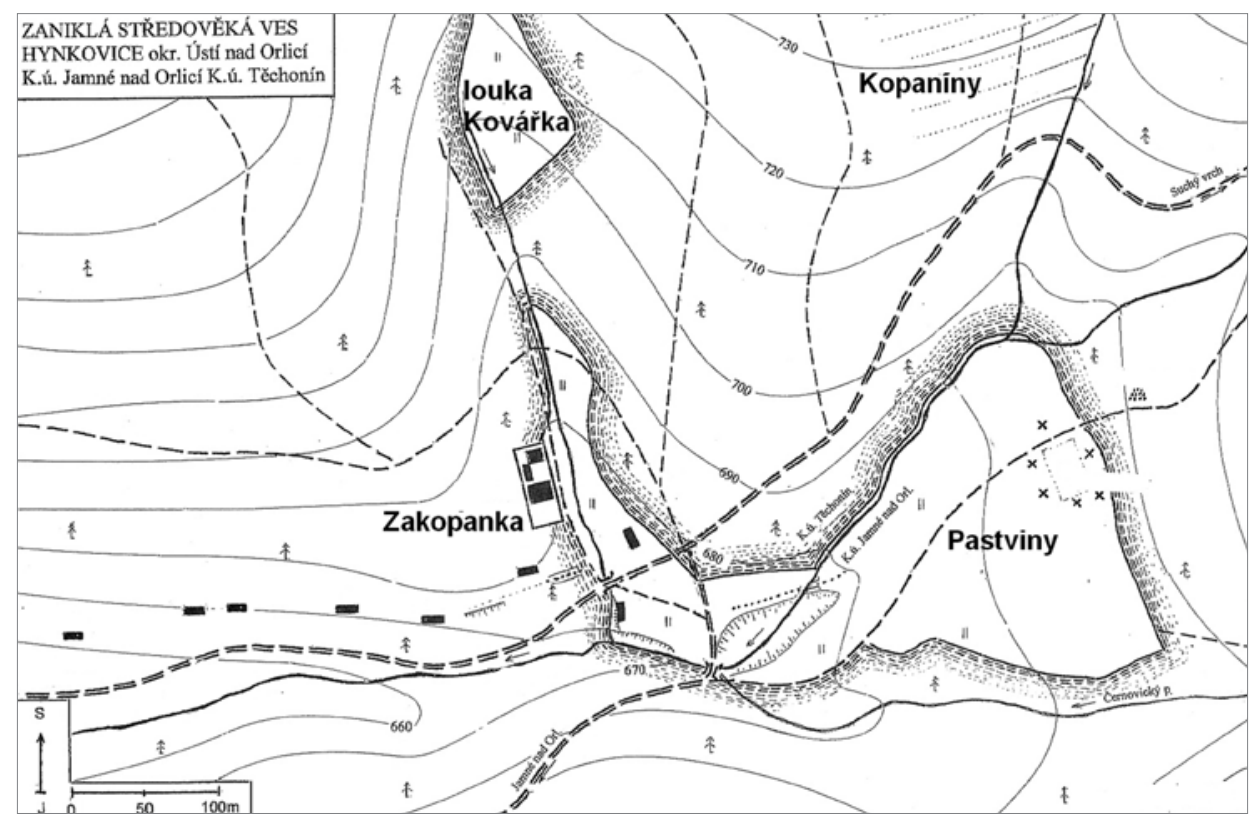

Obr. 7. Pracovní plán Hynkovic s předpokládanými plužinami.

Abb. 7. Arbeitsplanskizze von Hynkovice mit mutmaßlichen Flurstücken. 
kovou šroubovicí a červeným malováním (obr. 8:3, 6). Dna nádob nesou stopy podsýpky i odřezávání strunou. V keramických tvarech tradičně dominují hrnce, nezřídka opatřené okružími, objevily se však i jiné typy okrajů, jako kyjovitě zesílený aj. Hojně máme zastoupené pokličky s knoflíkem (obr. 8:12; 9:2, 6, 8). Z ostatních tvarů se vedle mísy (obr. 8:2) objevil snad i pohár nebo džbán (obr. 8:5, 11, 14).

I přes nedostatečný stav poznání východočeské vrcholně stř̌edověké keramiky (což zvláště platí pro Orlické hory, málo dotčené archeologickým poznáním) soubor keramiky poskytuje přece jenom určité informace. Některé střepy (např. zlomek okraje hrnce z usedlosti č. 3, obr. 8:10) ještě svým technologickým zpracováním odkazují na tradici 13. století, aplikace tohoto zpracování na okruží nás však vede na samý závěr tohoto věku, či spíše počátek věku následujícího. Do 14. století pak lze vzhledem k morfologii a zpracování hrnčiny klást většinu keramiky z Hynkovic. K některým typům okrajů lze nalézt př́mé analogie z lokalit datovaných spíše do první poloviny 14. století (Litomyšl - Bohemiatex, vrstvy datované dendrochronologicky - Vích 2016a, obr. 16:8; Zářecká Lhota - Hrádníky, hrádek s nálezy keramiky a kovové industrie včetně mincí - Vích 2016, obr. 14:7-8; hrádek v k. ú. Lanšperk - Vích 2010, obr. 7:2-3). Otázkou zůstává doba zániku lokality. Na základě některých znaků jako nálezy den odřezávané strunou či některé typy okrajů (okraj hrnce z usedlosti č. 1, obr. 8:3) lze dovodit, že zanikla v pokročilém 14. či ve starším úseku 15. století. Keramické zboží vyspělého 15 . století v souboru již postrádáme.

\subsection{Kovové predměty}

Z lokality dnes díky detektorové prospekci máme celkem okolo 70 ks železných předmětů, jeden kroužek ze slitiny mědi a dvě stříbrné mince. Pokud uvádíme souřadnice, jsou opět ve formátu UTM, WGS 84, zaměřené ruční stanicí GPS značky Garmin OREGON 550.

\section{Zemědělské nářadí}

bez č. hrotová část čepele srpu, $193 \times 13 \times 5 \mathrm{~mm}$; z areálu usedlosti č. 3 (obr. 10:4)

bez. č. zlomek čepele srpu s částí řapu, $141 \times 15 \times 7 \mathrm{~mm}, \mathrm{z}$ areálu usedlosti č. 3 (obr. 10:6)

bez. č. zlomek čepele srpu s částí řapu, $116 \times 13 \times 4 \mathrm{~mm}, \mathrm{z}$ areálu usedlosti č. 5 (nekresleno)

21. zlomek čepele srpu, $82 \times 16 \times 5 \mathrm{~mm}$, E 0618288 , N 5545511, z okolí usedlosti č. $6, \mathrm{hl} .22 \mathrm{~cm}$ na rozhraní povrchové humusové vrstvy a blíže nepoznané intaktní archeologické situace spolu s keramikou (nekresleno)

23. na dvě části rozlomená hrotová partie čepele srpu, $149 \times 11 \times 4 \mathrm{~mm}, 81 \times 9 \times 3 \mathrm{~mm}$, E 0618343 , $\mathrm{N} 5545552$, hl. $24 \mathrm{~cm}$ pod $11 \mathrm{~cm}$ mocnou humusovou vrstvou, $13 \mathrm{~cm}$ v hnědošedé vrstvě v kamenné destrukci pece usedlosti č. 5 (obr. 10:3)

25. zlomek čepele srpu, $124 \times 11 \times 5$ mm, E 0618344 , N 5545549, z okolí usedlosti č. 5, hl. $16 \mathrm{~cm}$, $\mathrm{z}$ toho $4 \mathrm{~cm}$ ve sterilním hnědošedém podloží (nekresleno)

33. hrotová partie čepele srpu, $277 \times 14 \times 5 \mathrm{~mm}$, E 0618522, N 5545559, pod usedlostí č. 3, hl. $10 \mathrm{~cm} v$ povrchové humusové vrstvě (nekresleno)

34. zlomek čepele srpu, $120 \times 13 \times 4$ mm, E 0618530, N 5545571, z usedlosti č. 3, hl. $20 \mathrm{~cm}$, z toho $8 \mathrm{~cm}$ ve sterilním šedohnědém podloží (nekresleno)

37. zlomek čepele srpu s částí řapu, $149 \times 15 \times 4$ mm, E 0618513 , N 5545586, z širšího okolí usedlosti č. 3, hl. $30 \mathrm{~cm}, \mathrm{z}$ toho $6 \mathrm{~cm}$ ve sterilním hnědošedém podloží (obr. 10:5)

40. celý srp, $381 \times 16 \times 5$ mm, E 0618571 , N 5545604, z okolí usedlosti č. 2, hl. 15 cm na rozhraní humusové vrstvy a hnědošedého podloží (obr. 10:1)

\section{Řemeslnické nástroje}

bez č. část pružinových nůžek, $126 \times 21 \times 8 \mathrm{~mm}$, z usedlosti č. 4 (obr. 11:1)

bez č. nebozez, $250 \times 17 \times 10 \mathrm{~mm}$, z tzv. usedlosti č. 9 , hl. do $15 \mathrm{~cm}$ (obr. 11:4)

1. lžícovitý vrták (?), $329 \times 21 \times 11$ mm, E 0618622, N 5545605, z usedlosti č. 2 (obr. 11:5) 


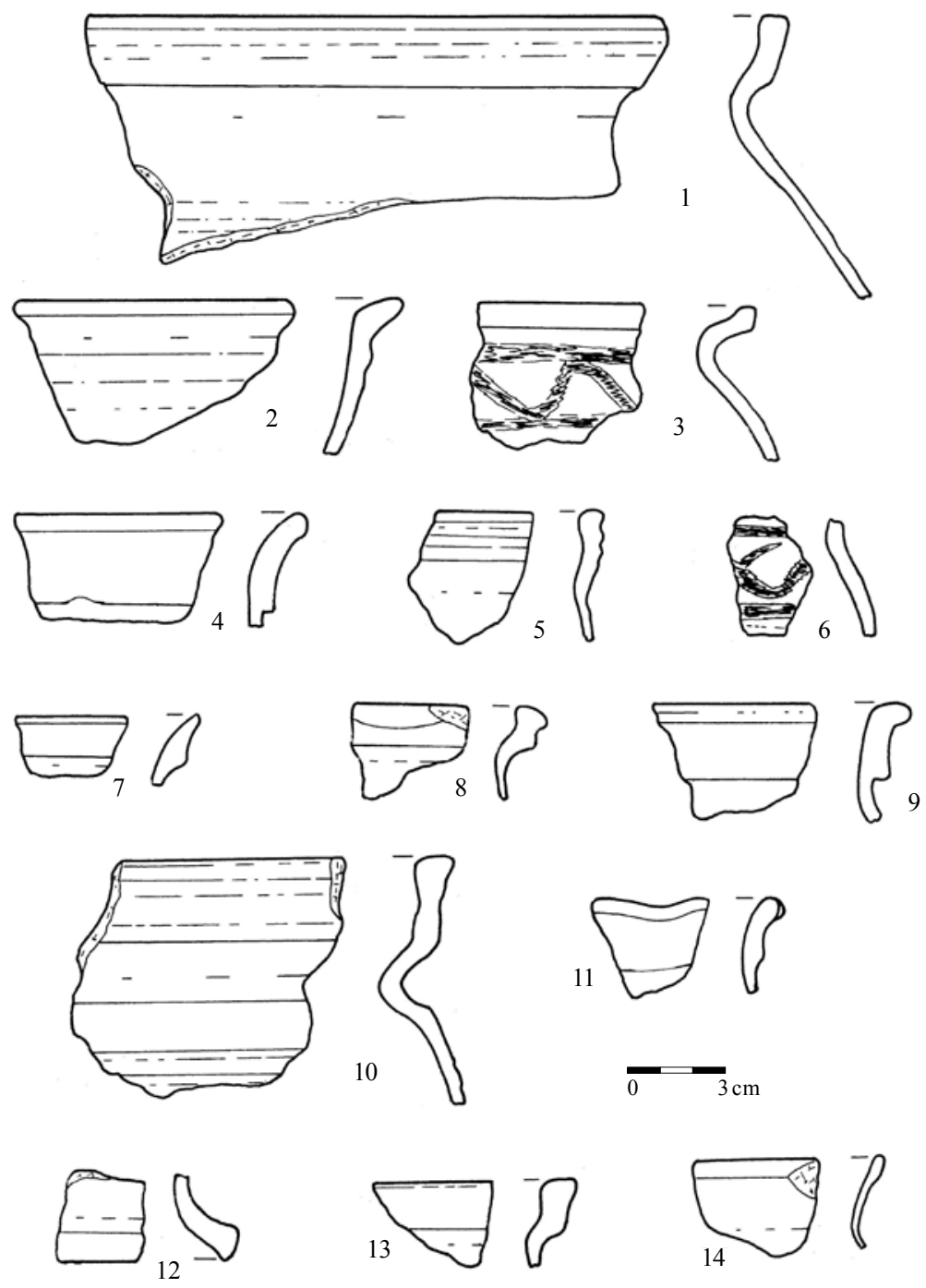

Obr. 8. Nálezy keramiky z Hynkovic. 1-9 - usedlost č. 1; 10-14 - usedlost č. 3.

Abb. 8. Keramikfunde aus Hynkovice. 1-9 - Anwesen Nr. 1; 10-14-Anwesen Nr. 3.

28. šídlo (?), $266 \times 9 \times 7 \mathrm{~mm}$, E 0618388 , N 5545549, z prostoru mezi usedlostmi č. 4 a 5, hl. $9 \mathrm{~cm}$, $\mathrm{z}$ toho $5 \mathrm{~cm}$ v šedohnědém podloží ve svahu (obr. 11:3)

38. část pružinových nůžek, $173 \times 15 \times 10 \mathrm{~mm}$, E 0618583 , N 5545586, z prostoru mezi usedlostmi č. 2 a 3, hl. $20 \mathrm{~cm}, \mathrm{z}$ toho $9 \mathrm{~cm}$ ve sterilním šedohnědém podloží (obr. 11:2)

41. celé kladívko, $143 \times 33 \times 26 \mathrm{~mm}$, E 0618591, N 5545616, při okraji usedlosti č. 2, hl. $40 \mathrm{~cm}$, z toho $36 \mathrm{~cm}$ je žlutavá vrstva charakteru podloží (obr. 11:6)

\section{Výstroj koně a jezdce}

bez č. zlomek ramene ostruhy, $58 \times 17 \times 6 \mathrm{~mm}$, při provádění mikrovrypu u usedlosti č. 1 (obr. $12: 8)$ 

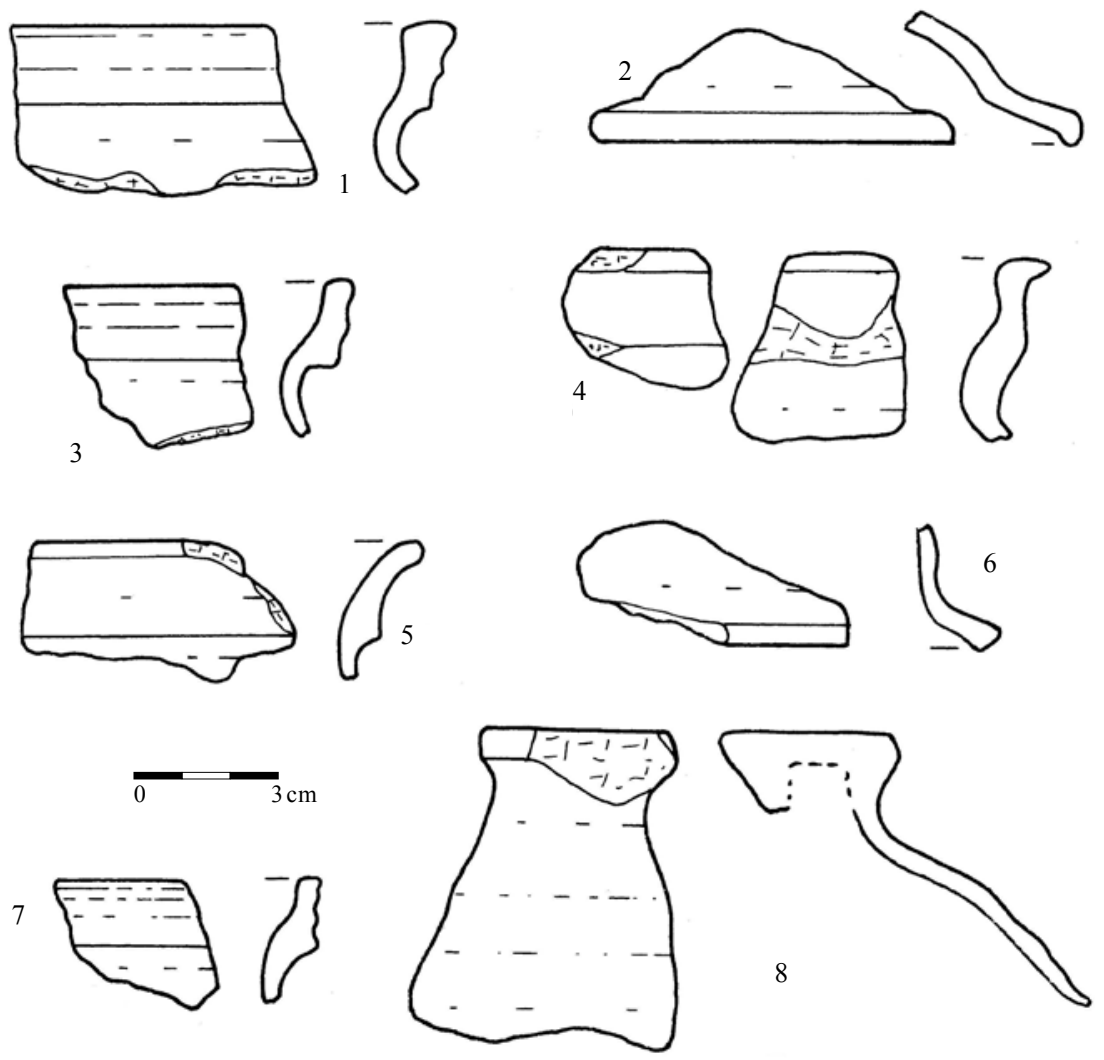

Obr. 9. Nálezy keramiky z Hynkovic. 1-3 - usedlost č. 4; 4, 7 - usedlost č. 5; 5-6 - usedlost č. 7; 8 - tzv. usedlost č. 9. Abb. 9. Keramikfunde aus Hynkovice. 1-3 - Anwesen Nr. 4; 4, 7 - Anwesen Nr. 5; 5-6 - Anwesen Nr. 7; 8 - sog. Anwesen Nr. 9.

bez č. zlomek třmene, $86 \times 48 \times 18 \mathrm{~mm}$, z usedlosti č. 4 (obr. 12:2)

2. polovina stíhlového udidla, $141 \times 77 \times 22 \mathrm{~mm}$, E 0618456, N 5545578, z usedlosti č. 4, hl. $32 \mathrm{~cm}$, $\mathrm{z}$ toho14 cm šedohnědá jílovitohlinitá s ojedinělým střepem (obr. 12:1)

3. polovina podkovy s ozubem bez hmatce, E 0618458, N 5545571, z usedlosti č. 4, hl. $22 \mathrm{~cm}$, $10 \mathrm{~cm}$ z šedé prachovité vrstvy spolu s č. 4 a 5 a keramikou (obr. 12:4)

12. polovina podkovy s ozubem, $121 \times 29 \times 24 \mathrm{~mm}$, E 0618199 , N 5545573, západně od usedlosti č. 6 , hl. $14 \mathrm{~cm}$ v povrchové humusové vrstvě (obr. 12:3)

15. polovina podkovy s ozubem bez hmatce, $113 \times 25 \times 16 \mathrm{~mm}$, E 0618221 , N 5545517, západně od usedlosti č. 6, hl. $5 \mathrm{~cm}$ v povrchové humusové vrstvě (obr. 12:6)

19. část podkovy s ozubem, $98 \times 21 \times 12 \mathrm{~mm}$, E 0618239 , N 5545546, západně od usedlosti č. 6 , hl. $14 \mathrm{~cm}$ v povrchové humusové vrstvě (obr. 12:5)

36. zlomek ramene podkovy, $76 \times 30 \times 4 \mathrm{~mm}$, E 0618564 , N 5545583, z prostoru mezi usedlostmi č. 2 a 3, na povrchu volně pod listím (obr. 12:9)

43. polovina podkovy, v místě lomu druhotně deformovaná, $103 \times 26 \times 15 \mathrm{~mm}$, E 0618595 , N 5545594, z usedlosti č. 2, hl. $30 \mathrm{~cm}$, z toho $17 \mathrm{~cm}$ v šedohnědém podloží (obr. 12:7) 


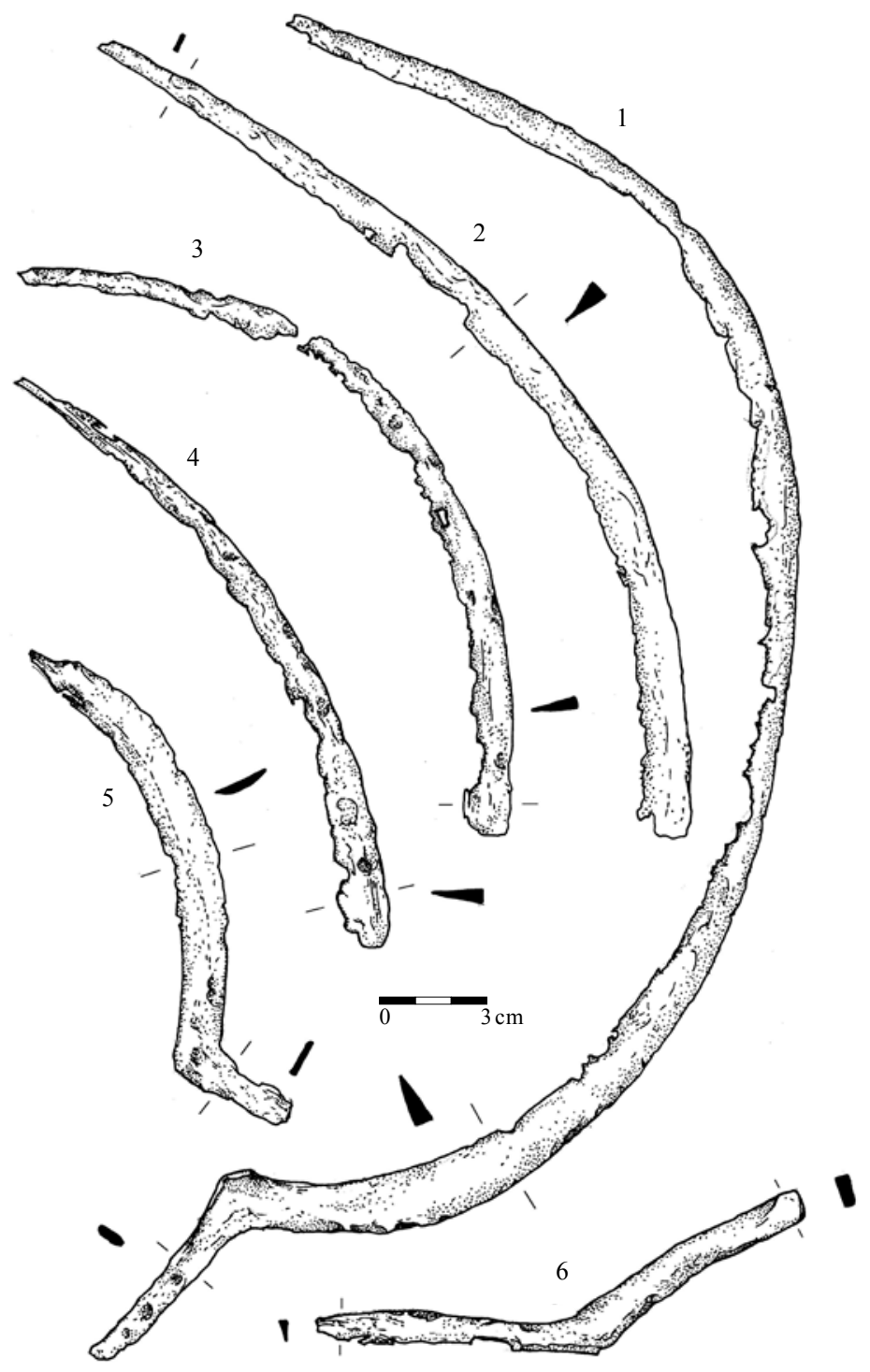

Obr. 10. Hynkovice. Nálezy srpů. Kresba Kristýna Urbanová.

Abb. 10. Hynkovice. Sichelfunde. Zeichnung Kristýna Urbanová.

\section{Stavební kování a uzamykací mechanismy}

bez č. jednoramenná skoba, $51 \times 28 \times 5 \mathrm{~mm}$, z usedlosti č. 4 (obr. 13:7)

6. otočný klíč s plným dříkem a částečně odlomeným kosočtverečným okem a bradou (původně součást č. 45$), 117 \times 38 \times 8 \mathrm{~mm}$, E 0618386 , N 5545561, mezi usedlostmi č. 3 a 4, hl. $10 \mathrm{~cm}$, z toho $3 \mathrm{~cm}$ v šedohnědém sterilním podloží (obr. 13:2)

20. oko s trnem, $40 \times 20 \times 4 \mathrm{~mm}$, E 0618274 , N 5545528, z usedlosti č. 5 , hl. $20 \mathrm{~cm}$ v povrchové humusové vrstvě (obr. 13:5) 

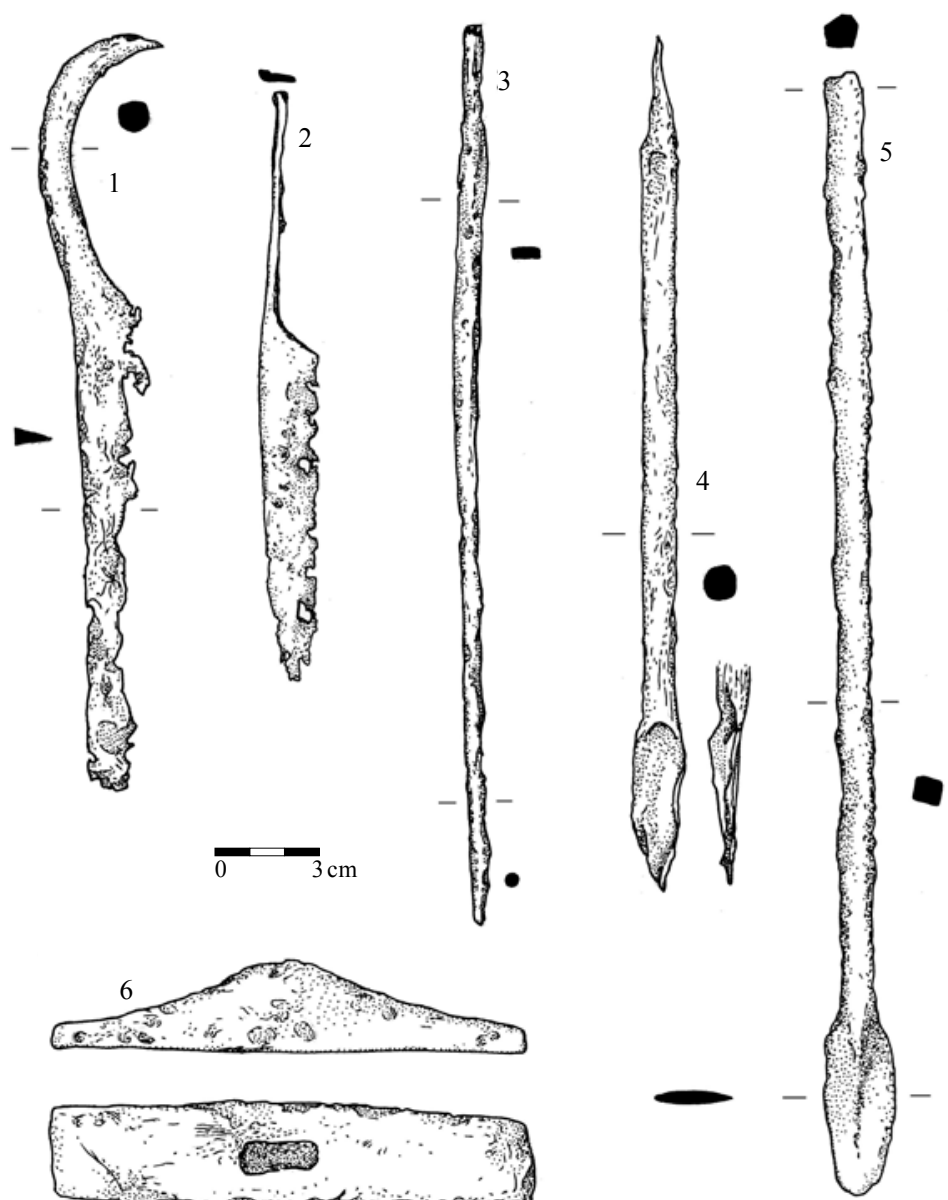

Obr. 11. Hynkovice. Řemeslné nástroje. Kresba Kristýna Urbanová. Abb. 11. Hynkovice. Werkzeuge. Zeichnung Kristýna Urbanová.

30. pásová závora, $180 \times 30 \times 7 \mathrm{~mm}$, E 0618487 , N 5545573, mezi usedlostmi č. 3 a 4,hl. $30 \mathrm{~cm}$, z toho $10 \mathrm{~cm}$ ve sterilním šedohnědém podloží (obr. 13:6)

42. oko s trnem s navlečeným oválným článkem, $30 \times 50 \times 34 \mathrm{~mm}$, E 0618600 , N 5545613 , $\mathrm{z}$ usedlosti č. 2 , hl. $25 \mathrm{~cm}, \mathrm{z}$ toho $7 \mathrm{~cm}$ v červenohnědé vrstvě charakteru podloží mezi kameny (obr. 13:4)

44. otočný klíč s dutým dříkem, $122 \times 40 \times 15$ mm, E 0618028 , N 5545577, mimo ZSV, západně od vsi, hl. $14 \mathrm{~cm}$ na rozhraní humusové vrstvy a podloží (obr. 13:3)

45. zlomek kosočtverečného oka otočného klíče (původně součást $\mathrm{s}$ č. 6 ), $31 \times 21 \times 4 \mathrm{~mm}$, E 0618394, N 5545560, mezi usedlostmi mezi č. 3 a 4, hl. $8 \mathrm{~cm}$, z toho $2 \mathrm{~cm}$ ve sterilním šedohnědém podloží (obr. 13:1)

\section{Militaria}

bez č. záštitný trn tesáku, $27 \times 27 \times 9$ mm, z usedlosti č. 4 (obr. 14:3) 


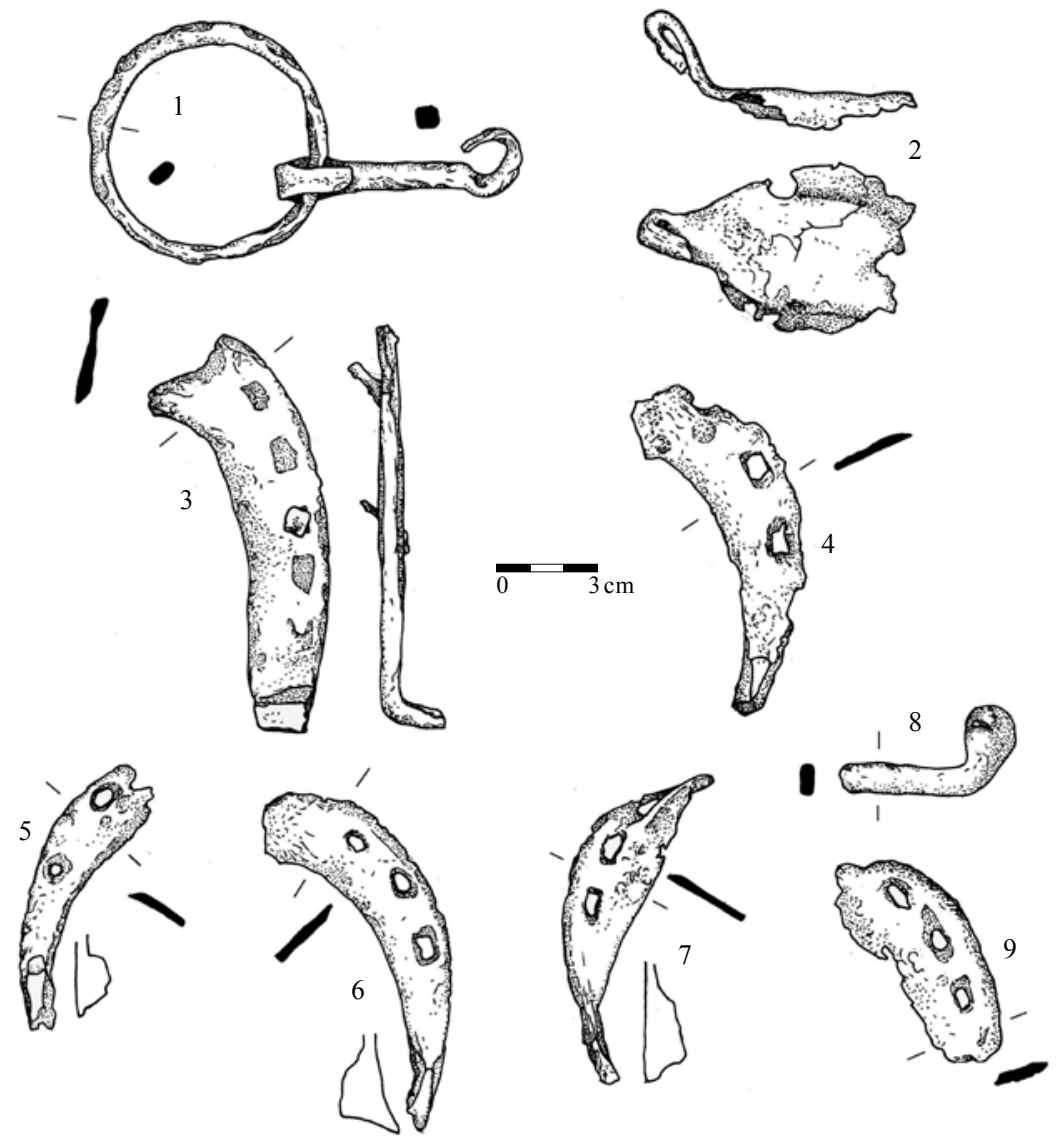

Obr. 12. Hynkovice. Výstroj jezdce a koně. Kresba Kristýna Urbanová.

Abb. 12. Hynkovice. Pferd- und Reiterausrüstung. Zeichnung Kristýna Urbanová.

7. silně korodovaný hrot šípu, $42 \times 9 \times 6 \mathrm{~mm}$, E 0618263 , N 5545550, z okolí usedlosti č. 6 , hl. $17 \mathrm{~cm}$ v humusové vrstvě (obr. 14:2)

8. masivní nůž či dýka s trnem pro nasazení rukojeti, $426 \times 23 \times 9$ mm, E 0618258, N 5545543, západně od usedlosti č. $6, \mathrm{hl} .14 \mathrm{~cm}$ na rozhraní humusové vrstvy a šedohnědého podloží (obr. 14:11)

9. torzo hrotu šípu, $63 \times 16 \times 8 \mathrm{~mm}$, E 0618278 , N 5545578, severně od usedlosti č. 6 , hl. $30 \mathrm{~cm}$, $\mathrm{z}$ toho $9 \mathrm{~cm}$ v šedohnědém podloží (obr. 14:1)

\section{Předměty osobní potřeby}

bez č. čepel nože s částí trnu, $107 \times 20 \times 3 \mathrm{~mm}$, z usedlosti č. 3 (obr. 14:7)

bez č. nůž s trnem s odlomeným hrotem, $145 \times 19 \times 4 \mathrm{~mm}$, z usedlosti č. 3 (obr. 14:5)

bez č. ocílka bikonvexního tvaru, $77 \times 20 \times 4 \mathrm{~mm}$, z usedlosti č. 4 (obr. 15:3)

bez č. čepel nože s částí trnu, $129 \times 14 \times 3 \mathrm{~mm}$, z usedlosti č. 6 (obr. 14:4)

bez č. čepel nože, $84 \times 15 \times 4 \mathrm{~mm}$, z usedlosti č. 6 (obr. 14:8) 

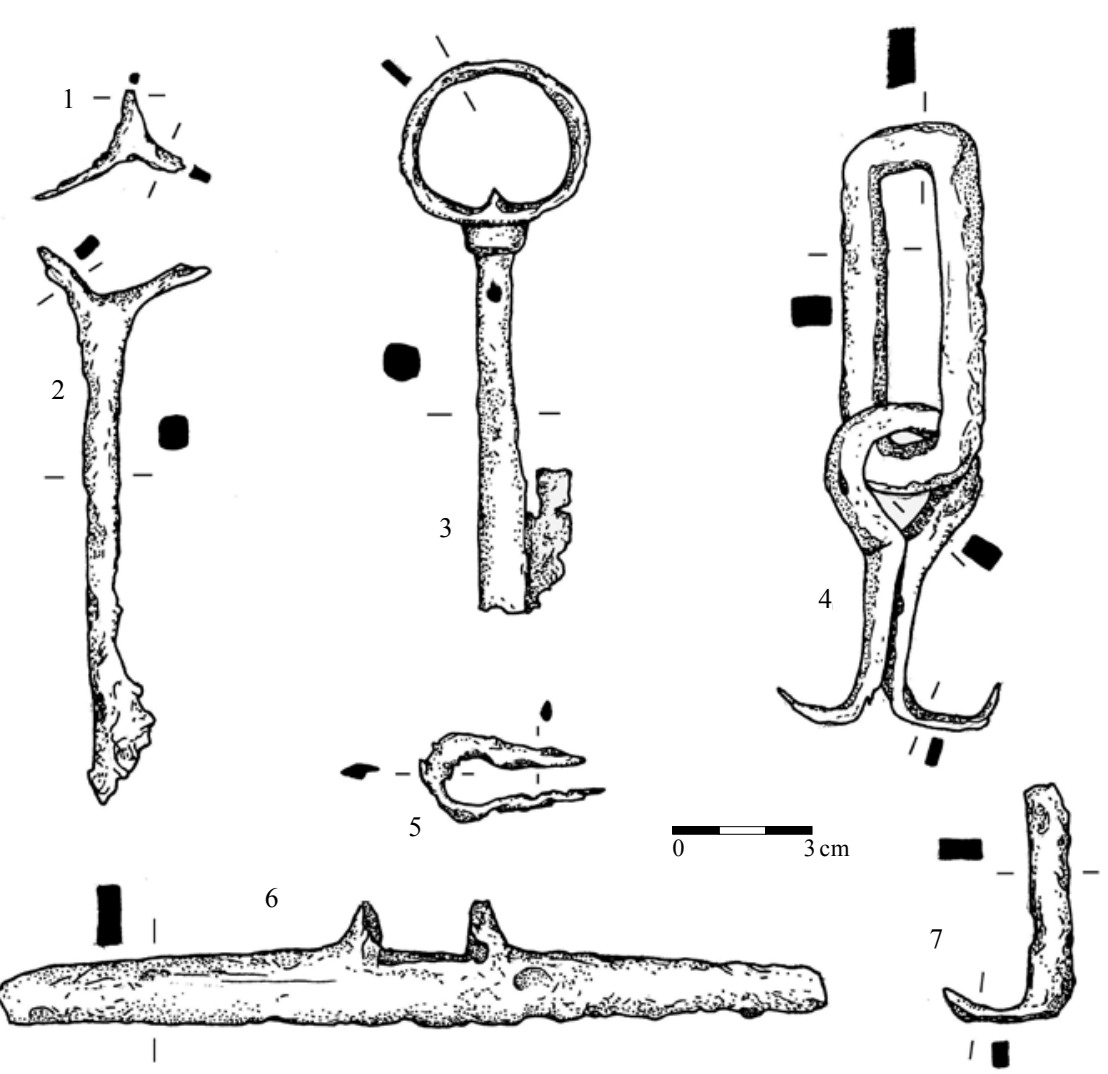

Obr. 13. Hynkovice. Stavební kování a části uzamykacích mechanismů. Kresba Kristýna Urbanová. Abb. 13. Hynkovice. Baubeschläge und Teile von Schließmechanismen. Zeichnung Kristýna Urbanová.

10. rámeček přezky ve tvaru D s trnem, rámeček $52 \times 26 \times 3 \mathrm{~mm}$, trn $30 \times 9 \times 3 \mathrm{~mm}, \mathrm{E} 0618244$, N 5545587, severozápadně od usedlosti č. $6, \mathrm{hl} .18 \mathrm{~cm}$ na rozhraní tmavé povrchové vrstvy a šedohnědého podloží (obr. 15:2)

11. rozpadlá trapézovitá přezka, neměřitelné, E 0618236, N 55455651, západně od usedlosti č. 6 , hl. $10 \mathrm{~cm}$ na rozhraní humusové vrstvy a podloži (nekresleno)

13. zlomek čepele nože, $119 \times 19 \times 5 \mathrm{~mm}$, E 0618231 , N 5545544, západně od usedlosti č. $6, \mathrm{hl} .22 \mathrm{~cm}$, z toho $12 \mathrm{~cm}$ v šedohnědém podloží v okraji vývratu (nekresleno)

16. oválně obdélný rámeček přezky, $61 \times 42 \times 5 \mathrm{~mm}$, E 0618238 , N 5545553, západně od usedlosti č. $6, \mathrm{hl} .27 \mathrm{~cm}$, z toho $4 \mathrm{~cm}$ v hnědošedém podloží (obr. 15:1)

17. silně korodovaná čepel nože se zbytkem trnu, $92 \times 10 \times 3$ mm, E 0618242 , N 5545555, západně od usedlosti č. 6, hl. $20 \mathrm{~cm}$ na rozhraní humusové vrstvy a šedohnědého podloží (obr. 14:10)

18. prakticky rozpadlá čepel nože, neměřitelné, E 0618249, N 5545551, západně od usedlosti č. 6, hl. $20 \mathrm{~cm}$ na rozhraní humusové vrstvy a podloží (nekresleno)

26. nůž s trnem a subtilní čepelí, $83 \times 12 \times 3 \mathrm{~mm}$, E 0618347, N 5545552, mezi usedlostmi č. 5 a $6, h 1.22 \mathrm{~cm}$, z toho $8 \mathrm{~cm}$ v šedohnědém podloží (obr. 14:9)

27. deformované torzo nože s řapem s nýtky, $111 \times 13 \times 12 \mathrm{~mm}$, E 0618340, N 5545559, mezi usedlostmi č. 5 a 6, hl. $22 \mathrm{~cm}$, z toho $8 \mathrm{~cm}$ v šedohnědém podloží (obr. 14:6) 
39. silně korodovaná čepele nože, $98 \times 12 \times 2 \mathrm{~mm}$, E 0618583 , N 5545581, mezi usedlostmi č. 2 a 3, hl. $12 \mathrm{~cm}$ v humusové vrstvě (nekresleno)

\section{Ostatní a neidentifikované artefakty}

bez č. hrotitý předmět ukončený mezikružím, $74 \times 24 \times 5 \mathrm{~mm}$, z usedlosti č. 2 (obr. 15:11)

bez č. hákovitý předmět, $77 \times 42 \times 20 \mathrm{~mm}$, z usedlosti č. 2 (obr. 15:10)

bez č. železný kruh, d $73 \mathrm{~mm}$, v. $6 \mathrm{~mm}$, z usedlosti č. 3 (nekresleno)

bez č. silně korodovaný hákovitě prohnutý železný pásek, $97 \times 14 \times 4 \mathrm{~mm}$, z usedlosti č. 3 (nekresleno)

bez č. plný hrotitý artefakt, $124 \times 17 \times 14 \mathrm{~mm}, \mathrm{z}$ usedlosti č. 4 (obr. 15:6)

bez č. železný kroužek, d 41 mm, v. $6 \mathrm{~mm}$, z usedlosti č. 4 (nekresleno)

bez č. torzo omegovitého předmětu vykovaného ze železného pásu, $43 \times 32 \times 7 \mathrm{~mm}$, z usedlosti č. 5 (obr. 15:7)

bez č. štítkovitý předmět se středovým otvorem, $46 \times 18 \times 2 \mathrm{~mm}$, z usedlosti č. 5 (nekresleno)

bez č. omegovitý artefakt vykovaný z železného pásu, $61 \times 38 \times 9 \mathrm{~mm}$, z usedlosti č. 6 (obr. 15:4)

4. příčně prohnutý pás železného plechu s otvory, $154 \times 23 \times 8 \mathrm{~mm}$, E 0618438, N 5545571, $\mathrm{z}$ usedlosti č. 4, hl. $22 \mathrm{~cm}, 10 \mathrm{~cm}$ z šedé prachovité vrstvy spolu s č. 3 a 5 a keramikou (obr. 15:5)

5. železná destička, $31 \times 25 \times 3 \mathrm{~mm}$, E 0618458, N 5545571, z usedlosti č. 4, hl. $22 \mathrm{~cm}, 10 \mathrm{~cm}$ z šedé prachovité vrstvy spolu s č. 4 a 3 a keramikou (nekresleno)

14. pásovitý artefakt plankonvexního prríčného průřezu, $176 \times 20 \times 6 \mathrm{~mm}$, E 0618221 , N 5545516, západně od usedlosti č. 6, hl. $30 \mathrm{~cm}$, v šedohnědém podloží u kořene stromu (obr. 15:8)

22. kroužek ze slitiny mědi, d $40 \mathrm{~mm}$, v. $3 \mathrm{~mm}$, E 0618324 , N 5545528, mezi usedlostmi č. 5 a $6, \mathrm{hl} .25 \mathrm{~cm}, \mathrm{z}$ toho $10 \mathrm{~cm}$ v šedohnědém podloží (nekresleno)

24. želený kroužek, d 39 mm, v. 3 mm, E 0618343, N 5545552, z usedlosti č. 5, hl. $20 \mathrm{~cm}$, z toho $4 \mathrm{~cm}$ v šedohnědém podloží (nekresleno)

29. zlomek železného předmětu se zaoblenými hranami, $89 \times 26 \times 4$ mm, E 0618474, N 5545568, pod usedlostí č. $4, \mathrm{hl} .30 \mathrm{~cm}, \mathrm{z}$ toho $11 \mathrm{~cm}$ v šedohnědém podloží (nekresleno)

31. větší část kruhu s př́íčným průřezem ve tvaru U, d 43 mm, v. 3 mm, E 0618510, N 5545564, pod usedlostí č. 3, hl. $10 \mathrm{~cm}$ ve splachové vrstvě (nekresleno)

32. silně korodovaný předmět s ostřím, $64 \times 19 \times 3 \mathrm{~mm}$, E 0618510 , N 5545561, pod usedlostí č. 3 , hl. $12 \mathrm{~cm}$ na rozhraní humusové vrstvy a podloží (nekresleno)

35. zlomek pásu s ostř́ím, $140 \times 20 \times 6 \mathrm{~mm}$, E 0618527 , N 5545573, z usedlosti č. 3, hl. $27 \mathrm{~cm}$, $\mathrm{z}$ toho $7 \mathrm{~cm} v$ šedohnědé vrstvě mezi kameny v kupoli pece (obr. 15:9)

\section{Mince}

bez č. pražský groš Václava II., 27,5 × 27,2 mm, hmotnost 3,16 g, E 0618345, N 5545558, z usedlosti č. 5 (obr. 16)

bez č. pražský groš Václava II., 25,8 × 25,2 mm, hmotnost 3,63 g, E 0618275, N 5545535, z usedlosti č. 6 (obr. 17)

Zemědělské nástroje zastupují výhradně srpy a jejich zlomky, které se však na lokalitě objevují ve značném množství (výběr na obr. 10:1-6). Pokud umožňují klasifikaci, jedná se o typ I podle R. Krajíce $(2003,139)$ bez chronologického významu. Srpy či jejich části patří $\mathrm{k}$ velmi častým nálezům na vrcholně středověkých lokalitách.

V širším nálezovém spektru se objevují řemeslnické nástroje. Nepř́liš častým nálezem je kladívko se dvěma úzkými protilehlými pracovními plochami (obr. 11:6), nazývané proto jako kladívko naklepávací, vyklepávací či kosné (Drda 1978, 21; Belcredi 1989, 449; Krajíc 2003, 

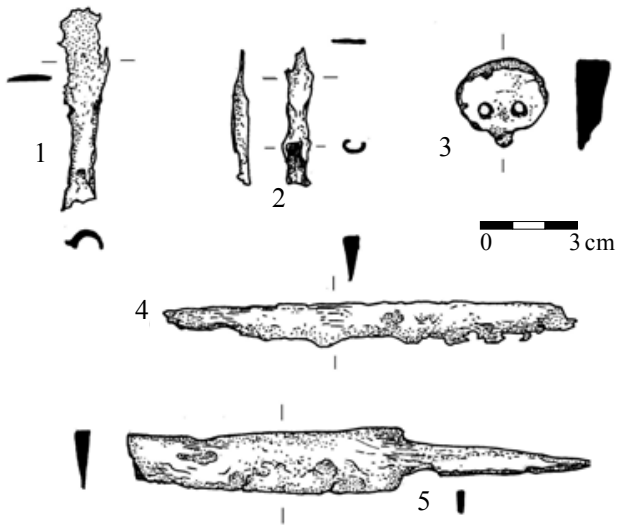

6
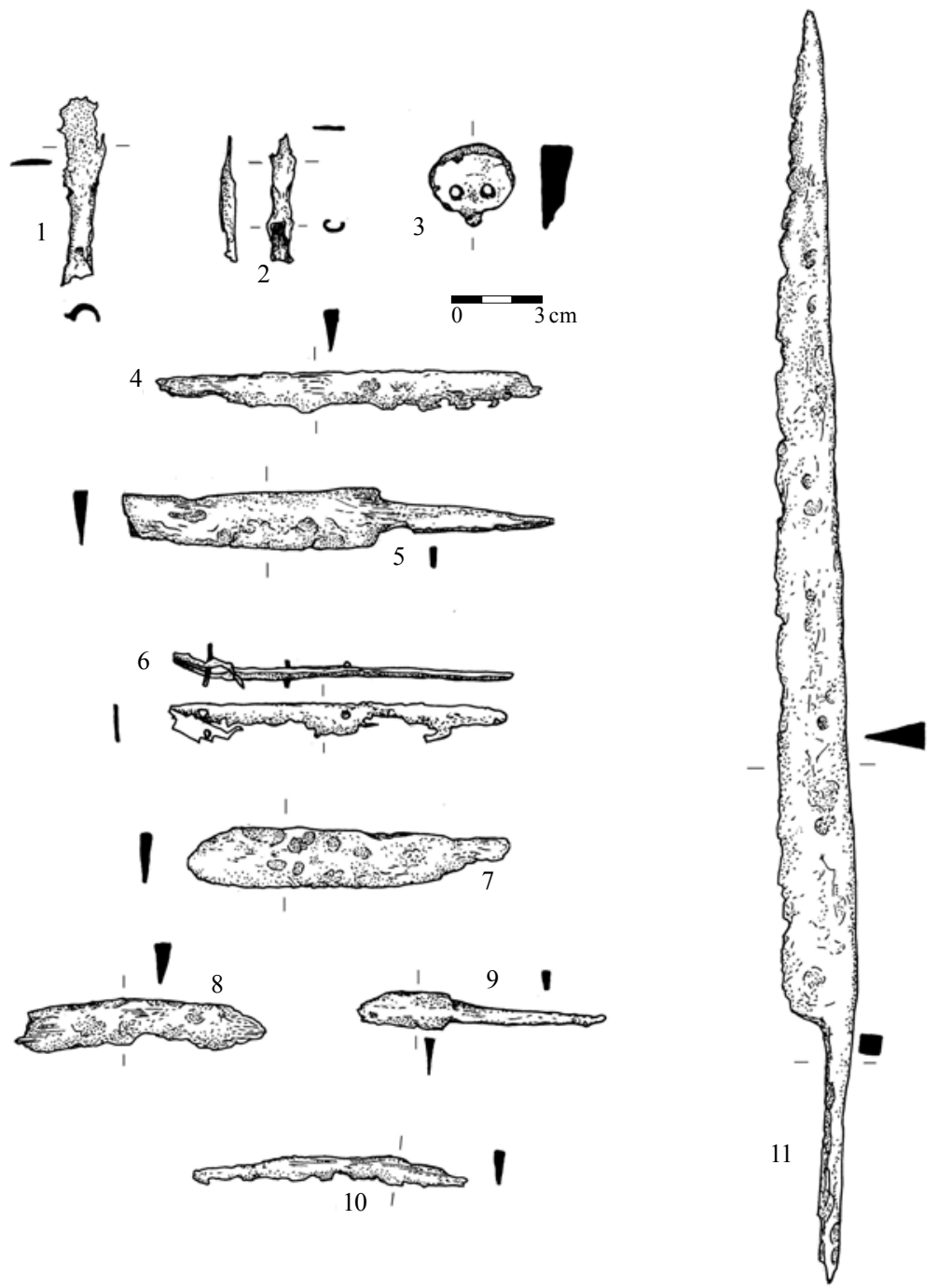

Obr. 14. Hynkovice. Militaria a předměty osobní potřeby. Kresba Kristýna Urbanová. Abb. 14. Hynkovice. Militaria und Gegenstände des persönlichen Bedarfs. Zeichnung Kristýna Urbanová.

164). Nálezem z kovárny v Sezimově Ústí (Krajíc 2003, obr. 28:17 269) máme tento typ kladiva doložen jako nástroj řemeslný, využití však takové nástroje nacházely i v zemědělství k naklepávání ostř́i zemědělského nářadí. Vedle nálezů ze Sezimova Ústí (Drda 1978, 12, II:15-16; Krajíc 2003, 164, tab. 132:2018-2019, 17 269) byla tato kladiva nalezena v Semonicích (Huml 1967, 10, V:17) a Bystřeci (Belcredi 1983, 417, tab. IV:1; 2006, 358-359, tab. XL:1).

Práci s dřevem dokládá nález nebozezu (obr. 11:4). S těmito nástroji se běžně setkáváme v různém sociálním prostředí včetně vesnického (např. Bystřec - Belcredi 2006, 359, tab. XL:69; Konůvky - Měchurová 1997, 92, tab. LV:3-7; Pfaffenschlag - Nekuda 1975, 145, obr. 140:2). Zajímavý předmět (č. 1) byl nalezen v areálu usedlosti č. 2 (obr. 11:5). Železný prut čtverhranného př́ičného průřezu nese lopatkovité ukončení. Nejbližší analogie nacházíme v podstatně starších souvislostech - jsou označovány jako lžícovité vrtáky a setkáváme se s nimi v raně 

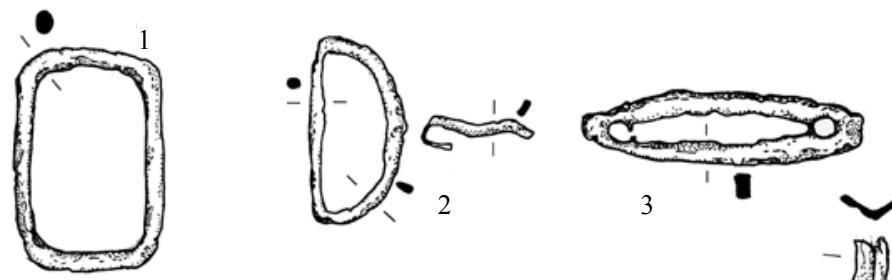

4
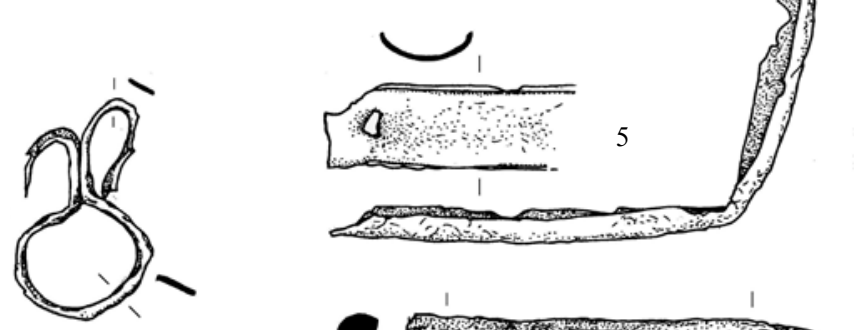

6
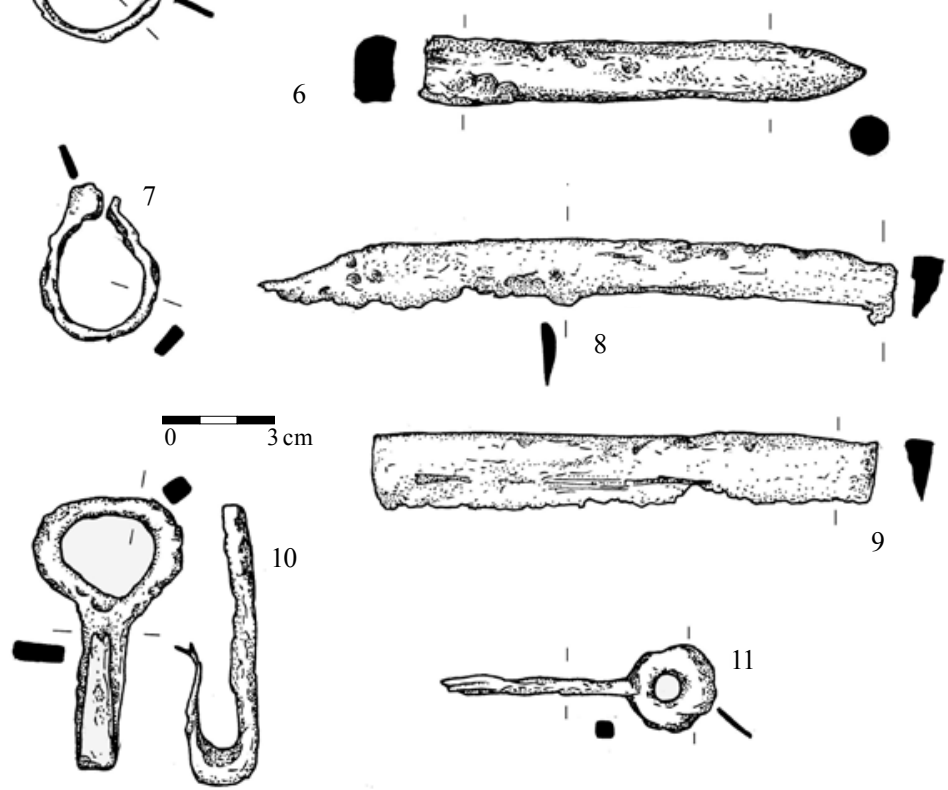

9

Obr. 15. Hynkovice. Předměty osobní potřeby a neurčené nálezy. Kresba Kristýna Urbanová.

Abb. 15. Hynkovice. Gegenstände des persönlichen Bedarfs und unbestimmte Funde. Zeichnung Kristýna Urbanová.

středověkých a starších kontextech (Bartošková 1986, 74). Je-li interpretace správná, pak se jedná o poměrně pozdní doklad přežívání tohoto archaického dřevoobráběcího nástroje.

Na pomezí zemědělského nářadí (stř́ihání ovcí), řemeslného nářadí (stř́íhání látky) a předmětů osobní potřeby (stříhání vousů a vlasů - Slivka 1981, 227) stojí pružinové nůžky doložené v Hynkovicích dvěma torzy (obr. 11:1-2). Zatímco torzo nůžek z usedlosti č. 4 patří k prvnímu typu podle M. Beranové (1967, 572-573), u něhož bylo péro nůžek tvořeno prostým obloukem, druhé torzo (č. 38) určit nedokážeme, protože se dochovala pouze břitová část, z níž není konstrukční řešení patrné. Bez ohledu na tuto skutečnost jsou používány pérové nůžky bez větších změn od doby laténské do novověku. 
$\mathrm{V}$ prrípadě hrotitého artefaktu č. 28 , který z kruhového příčného průřrezu postupně přechází v ploše obdélný, patrně nepochybíme, když ho označíme jako šídlo (obr. 11:3). Náleží k typu I podle R. Krajíce $(2003,152)$, opět bez možnosti přesnějšího datování.

Z výstroje koně a jezdce máme dochovány především zlomky podkov, část udidla, třmene a zlomek ramene ostruhy. Všechny podkovy (obr. 12:3-7, 9) jsou vykovány z pásu železa, který se směrem ke středu rozšiřuje, konce ramen nesou ozub. I když tyto podkovy lze zařadit do podrobnějších typologických schémat (Kaźmierczyk 1978; Krajíc 2003, 100-109), datování se obvykle pohybuje v širším intervalu 13.-15. století. Polovina udidla náleží k dvojdílným stíhlovým udidlům (obr. 12:1) a lze ji klasifikovat jako typ I podle A. Nadolského (1954, 87), II podle A. Ruttkaye (1976, 357-358), popř. typ 3 podle R. Krajíce (2003, 112). Udidla tohoto typu nejsou chronologicky citlivá (např. Nadolski 1954, 87; Ruttkay 1976, 357-358; Měchurová 1980, 189$190 ; 1984,276)$. Mnoho prostoru pro úvahy neposkytuje ani koncový zlomek ramene ostruhy se zakorodovaným kruhovým otvorem a torzo třmene (obr. 12:8). I když oba typy artefaktů obvykle poskytují chronologické informace, vzhledem ke stavu dochování předmětů z Hynkovic se musíme spokojit pouze s rámcovým datováním do vrcholného středověku.

Stavební kování tvoří běžně se vyskytující a chronologicky indiferentní součásti určené k zapuštění do pevného podkladu, jako jednoramenná skoba a oka s trnem (obr. 13:4, 5, 7), součástí uzavíracího mechanismu byla pásová závora (obr. 13:6, k této kategorii nálezů viz Krajíc 1991; 2003, 74-80). Stranou pozornosti zůstaly hojně př́itomné železné hřeby, pouze z tzv. usedlosti č. 9 bylo vyzvednuto několik kusů jako vzorek.

Více pozornosti zasluhují dva exempláře otočných klíčů. Klíč s kosočtverečnou hlavou nalezený neúplný ve dvou zlomcích nedaleko sebe (obr. 13:1-2) náleží k typu IX (Krajíc 1991, 332-333, obr. 9; 2003, 92, obr. 91). Původně byly počátky těchto klíčů hledány až ve 14. století, tento předpoklad se však ve světle nových nálezů ukázal jako neudržitelný a s jejich výskytem musíme počítat nejpozději od první čtvrtiny 13. století (Richter 1961; Dragoun 1992). Druhý
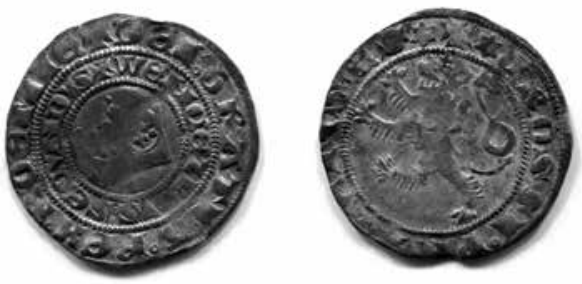

Obr. 16. Pražský groš Václava II. z usedlosti č. 5 v zaniklých Hynkovicích.

Abb. 16. Prager Groschen von Wenzel II. aus Anwesen Nr. 5 in der Dorfwüstung Hynkovice.
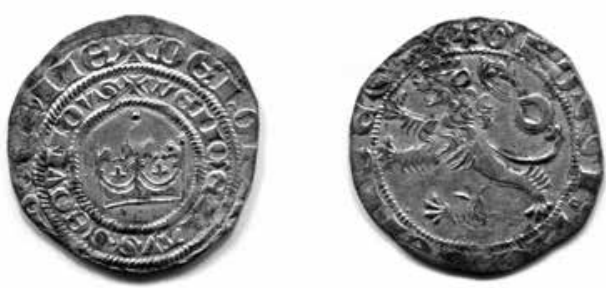

Obr. 17. Pražský groš Václava II. z usedlosti č. 6 v zaniklých Hynkovicích.

Abb. 17. Prager Groschen von Wenzel II. aus Anwesen Nr. 6 in der Dorfwüstung Hynkovice.

klíč představuje naopak podstatně vyspělejší typ klíče s dutým dříkem a hrotitým výběžkem vybíhajícím do oka (obr. 13:3). Náleží ke klíčům typu XII podle R. Krajíce (1991, 332, obr. 9; 2003, 92, obr. 90) s rozšířením od 15. století s možným časnějším výskytem (Slivka 1981, 237; Hoffmann-Mende 1995, 146-158; Krajíc 2003, 94). Tento klíč jsme však nalezli západně od areálu usedlosti č. 6 a zůstává otázkou, zda se zaniklou vesnicí souvisí, či jde o mladší izolovaný (ztracený) nález.

Z usedlosti č. 4 pochází záštitný trn tesáku vějířovitého tvaru se dvěma otvory (14:3). V poslední práci věnované tesákům jsou tyto záštitné trny klasifikovány jako typ t6 a patří k nejběžnějšímu typu záštitných trnů vůbec. Datovat je lze od závěru 14. až po 16. století (Žákovský 2014, 427-431). Jako zbraň s největší pravděpodobností sloužil předmět č. 8, o čemž svědčí jeho délka 
a šířka čepele (obr. 14:11). Jedná se o masivní nůž či pravděpodobněji (neznáme zpo̊sob upevnění a tvar rukojeti) o dýku (Žákovský 2014, 202; Žákovský-Hošek 2015, 221-223). Dva hroty šípů se dochovaly velmi poškozené, což znesnadňuje jejich klasifikaci. Původně nesly listovitý hrot a na ratiště šípu byly připevněny pomocí tuleje (obr. 14:1-2). S přihlédnutím ke stavu před konzervací jde o hroty typu II podle A. Nadolského $(1954,64)$ či T5-5 podle B. Zimmermanna (2000, 63-64), přičemž uvedení autoři šipky obdobných tvarů datují do období 9.-14. století.

Předměty osobní potřeby reprezentují nože, přezky a ocílka. Hojné zastoupení nožů v zaniklé vsi odpovídá potřebě a rozšíření těchto univerzálních nástrojů. Tradičně jsou rozdělovány na dvě skupiny podle způsobu upevnění rukojeti, a to nože s trnovitým řapem a plochým řapem. Typologicky starší jsou nože s trnovým řapem, které v Hynkovicích převládají (obr. 14:5, 9, 10), bez ohledu na tuto skutečnost však nože nepatři k chronologicky citlivým předmětům. Nože s plochým řapem reprezentuje jediný exemplář (obr. 14:6), ovšem stav některých nožů nedovoluje způsob upevnění rukojeti posoudit. Podobnou vypovídací schopnost mají i obě přezky (obr. 15:1-2), které mohly být součástí oděvu, výstroje koně či teoreticky i složkou vojenské výstroje.

Nepochybně běžnou součástí každodenního života člověka ve vrcholném středověku byla křesadla, i když se s nimi v nálezech nesetkáváme tak často jako s jinými typy artefaktů. S bikonvexními křesadly (obr. 15:3) se setkáváme ve Mstěnicích (např Nekuda 1985, 162, obr. 185:h), Pařidlech (Klápště 1994, obr. 61:11), Bystř̌eci (Belcredi 2006, 362, tab. XLII:6) a Hradišt'ku u Davle (Richter 1982, 158, obr. 103:2).

Z neželezných nálezů máme k dispozici pouze kroužek ze slitiny mědi (č. 22), u něhož však není jasné, zda se nejedná o recentní artefakt. Naopak, důležitým svědectvím o životě ve středověké vesnici jsou dvě mince, a to v obou př́ípadech pražské groše Václava II., nalezené v usedlostech č. 5 (obr. 16) a 6 (obr. 17) v počátcích detektorového průzkumu a dodatečně geodeticky zaměřené (obr. 5).

Nálezové spektrum doplňuje kolekce předmětů, která se zatím brání jednoznačnému určení. U některých předmětů není vyloučeno nízké stáří, protože s recentními předměty jsme se $\mathrm{v}$ daném prostoru rovněž setkávali.

Prostorové vyhodnocení jednotlivých kategorií nálezů v prostředí programu Quantum GIS nepřineslo žádná zásadnější zjištění, za povšimnutí stojí pouze významnější koncentrace zlomků srpů v okolí usedlostí č. 3 a 5, popř. mezi usedlostmi č. 2 a 3 (obr. 18), což může dokládat specifické aktivity vázané na tyto usedlosti. Zda tyto aktivity souvisí s konkrétní zemědělskou činností, nebo řemeslem (např. hrnčířství, srov. Krajíc 2003, 141), neumíme bez archeologického výzkumu rozhodnout. Dále je zajímavá koncentrace různých typů železných artefaktů západně od poslední usedlosti č. 6 , což patrně signalizuje nějaké další, blíže nezjištěné aktivity, snad přítomnost hospodářských staveb. V prŕípadě řemeslných nástrojů se projevuje výraznější koncentrace v závislosti na usedlosti č. $2(3 \mathrm{ks})$ a $9(2 \mathrm{ks})$, vzhledem ke statisticky nízkému počtu předmětů této kategorie a jejich nejednoznačnému přiřazení do kategorie řemeslných nástrojů (pružinové nůžky) nepřikládáme tomuto zjištění žádný význam.

\subsection{Kámen}

V areálu tzv. usedlosti č. 9 se našly dva pískovcové kameny tvořící dohromady jeden blok o rozměrech $325 \times 140 \times 115$ mm, který nese jasné stopy výrazného opálení a broušení. Jedná se o kámen intencionálně donesený člověkem a používaný k broušení.

\section{Závěr}

Na základě získaných archeologických pramenů můžeme konstatovat, že ves neznámého jména v ústní tradici označovaná jako Hynkovice vznikla dle nálezů keramiky př́i Černovickém potoku poblíž dnešní hájovny Zakopanka někdy v závěru 13. století či na samém počátku věku následujícího. K zániku vsi došlo v pokročilém 14. či ve starším úseku 15. století (nálezy keramiky, záštitný trn tesáku, otočný klíč s okem a dutým dříkem, pokud ovšem ten s vesnicí souvisí). Život na vesnici v průběhu 14. století rovněž dokládají nálezy dvou pražských grošů. Jaký 
byl důvod založení Hynkovic v tak nezvyklé a pro zemědělství nevhodné poloze, nevíme. Snad je lze spojit s kutacími pokusy na svazích Zlaté hory, jak měl být v dávných dobách nazýván Suchý vrch. Někdy v průběhu první poloviny 14. století byla v širším okolí údajně objevena ložiska kovů. ${ }^{2}$ Osvětlení př́ičin založení vsi a možné vazby založení na nerostné bohatství jsme si slibovali od detektorové prospekce, nutno ovšem říci, že v movitých nálezech jakékoliv nálezy, které bychom mohli spojit s hornickou činností, zatím postrádáme. Výrazný podíl obživy mimo agrární oblast ale musíme logicky předpokládat.

Půdorys osady Hynkovice se nejvíce blíží krátké lesní lánové vsi (Černý 1979, 57). Tomu ale neodpovídá tvar plužin, které z geomorfologických důvodů nemohou navazovat na jednotlivé usedlosti. Otázku půdorysného uspořádání Hynkovic však ponechme otevřenou, protože neznáme tvar a uspořádání plužin a bez archeologického výzkumu ani uspořádání (a v zásadě ani skutečný počet) jednotlivých usedlostí.

Celkem máme spolehlivě doloženo šest usedlostí (č. 1, 2, 3, 4, 5, 6), jednu velmi pravděpodobnou (č. 7) a ve dvou př́ípadech (č. 8,9) není možné říci, zda kumulace nálezů signalizují přítomnost usedlostí či (pravděpodobněji) dokládají jiné aktivity. Jednotlivé usedlosti byly postaveny ze dřeva na uměle zbudovaných plošinách ve svahu nad Černovickým potokem, kámen obyvatelé použili pouze ve specifických př́padech (kupolovité útvary interpretované snad jako pozůstatky destruovaných pecí, důvodně přepokládáme kamenné podezdívky). O podobě jednotlivých usedlostí a dalších doprovodných staveb nejsme schopni říci bez archeologického výzkumu nic. Dnešní podobu reliktů výrazně ovlivnily postdepoziční procesy, především svahová eroze a vývraty, prresto si zbytky vsi situované do zalesněného terénu mimo zemědělsky obdělávanou plochu uchovaly značný archeologický potenciál.

Dle výpovědi archeologických pramenů došlo k opuštění vesnice pokojným způsobem, přičemž odcházející obyvatelé s sebou odnesli použitelné vybavení; zdánlivé množství prezentovaných kovových předmětů je ovlivněno

2 František Grus, Kronika obce Jamné nad Orlici, s. 55.

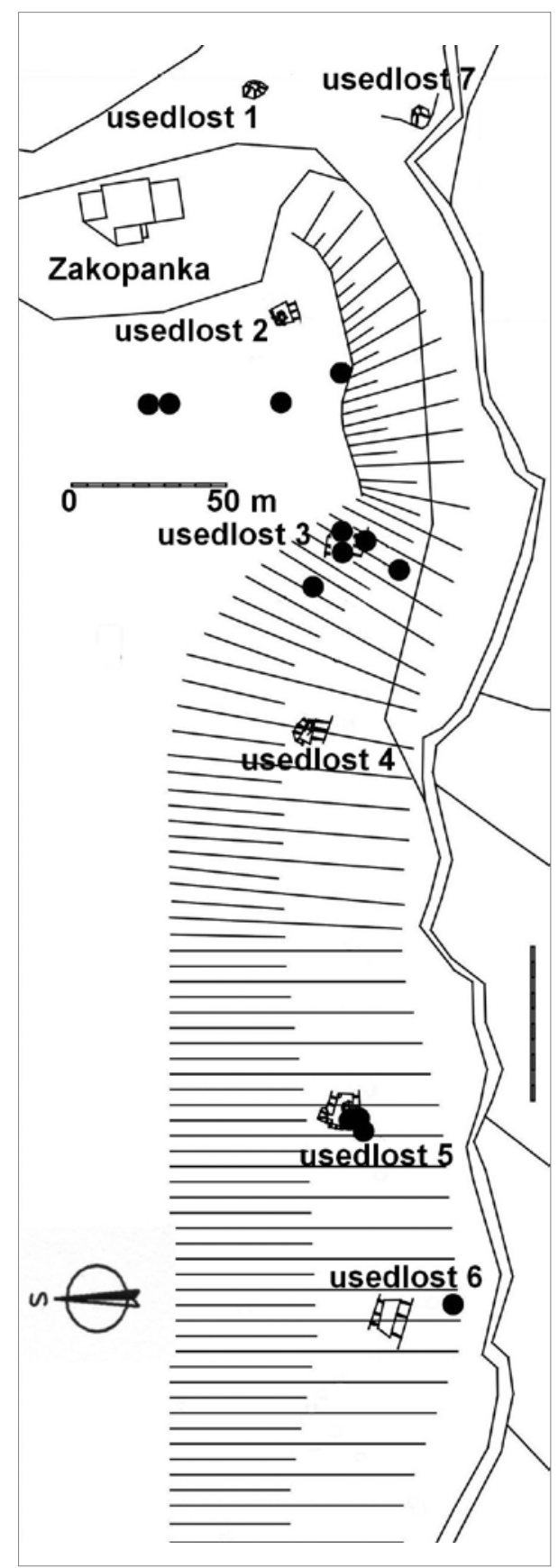

Obr. 18. Prostorová distribuce srpů a jejich částí v zaniklých Hynkovicích. Vyhotoveno v programu Quantum GIS. Abb. 18. Räumliche Verteilung der Sicheln und Sichelteile in der Dorfwüstung Hynkovice. Erstellt mit der Software Quantum GIS. 
délkou života vsi a především způsobem získání kovových předmětů (srov. zaniklý Spindelbach, kde byla detektorem zkoumána pouze část vsi - Hylmarová-Klír-Černá 2013, 575). Zánik osídlení ve spojitosti s válečnými událostmi se ve světle archeologických nálezů jeví jako značně nepravděpodobný. O př́ičinách se můžeme pouze dohadovat, svoji roli patrně sehrálo i umístění vesnice v zemědělsky nepř́íhodné oblasti. ${ }^{3}$

Provedený průzkum zaniklé středověké vesnice na rozhraní k. ú. Těchonín a Jamné nad Orlicí sice nedokáže ozřejmit počátky těchto obcí, přináší však jasné archeologické doklady o tom, že i při nejednoznačné výpovědi pramenů písemných musíme na počátku 14. století na horním toku Tiché Orlice s přítomností člověka reálně počítat a že nejpozději v této době zde vznikala také odpovídající komunikační sít'.

Článek byl vypracován v rámci programu aplikovaného výzkumu a vývoje národní a kulturní identity (NAKI II) č. DG16P02R031 (Moravské křižovatky).

\section{Literatura}

BARTOŠKOVÁ, A., 1986: Slovanské depoty železných předmětů v Československu. Studie Archeologického ústavu Československé akademie věd v Brně XIII/2. Praha.

BELCREDI, L., 1983: Zemědělské a řemeslné nástroje na zaniklých středověkých sídlištích - Landwirtschaftliches und handwerkliches Gerät aus Ortwüstungen, AH 8, 411-422.

- 1989: Terminologie, trrídění a kód středověkých kovových předmětů - Terminologie, Klasifitierung und Kode mittelalterliche metalischer Gegenstände, AH 14, 437-472.

- 2006: Bystřec. O založení, životě a zániku středověké vsi. Archeologický výzkum zaniklé středověké vsi Bystřece 1975-2005. Brno.

BERANOVÁ, M., 1967: Hradištní nůžky v Československu - Burgwallzeitliche Scheren in der Tschechoslowakei, PA LVIII, 571-579.

ČERNÝ, E., 1979: Zaniklé středověké osady a jejich plužiny. Praha.

- 1992: Výsledky výzkumu zaniklých středověkých osad a jejich plužin. Brno.

DRAGOUN, Z., 1992: Klíče z domu čp. 241/I v Husově ulici na Starém městě pražském. In: Sborník Společnosti přátel starožitností 3, 59-66. Praha.

DRDA, M., 1978: Soubor nálezů ze Sezimova Ústí, Husitský Tábor 1, 7-29.

HOFFMANN, B.-MENDE, J., 1995: Schloß \& Schlüssel. Berlin.

HUML, V., 1967: Zaniklá tvrz Semonice - Die untergegangene Festung in Semonice. Fontes Musei Reginaehradecensis Supplementum II. Hradec Králové.

HYLMAROVÁ, L.-KLÍR, T.-ČERNÁ, E., 2013: Železné předměty ze zaniklého Spindelbachu v Krušných horách. K výpovědi detektorového průzkumu - Eisengegenstände aus der Wüstung Spindelbach im Erzgebirge. Zur Aussagekraft einer Detektorsuche, AH 38, 569-609.

KAŹMIERCZYK, J., 1978: Podkowy na Śląsku w X-XIV wieku. Studia z dziejów kultury materilanej. Prace Komisji Nauk Humanistycznych Nr. 9. Wrocław - Warszawa - Kraków - Gdańsk.

KLÁPŠTĚ, J., 1994: Pamět’ krajiny středověkého Mostecka. Most.

KLÍR, T.-KENZLER, H., 2009: Srovnávací studium areálů zaniklých středověkých vesnic na základě analýz fosforečnanů. Zaniklá středověká vesnice Schwarzenbach u Chebu - Vergleichende Untersuchungen von Arealen mittelalterlicher Ortswüstungen anhand von Phosphatanalysen. Die mittelalterliche Ortwüstung Schwarzenbach bei Cheb (Eger), AH 34, 657-680.

KRAJÍC, R., 1991: Stavební železo a uzavírací mechanismy na vrcholně středověkých lokalitách Táborska - Eiserne Baubeschläge und Verschließungsmechanismen von den hochmittelalterlichen Lokalitäten in der Gegend von Tábor, AH 16, 323-344.

- 2003: Sezimovo Ústí. Archeologie středověkého poddanského města 3. Kovárna v Sezimově Ústí a analýza výrobků ze železa. Díl I. Praha - Sezimovo Ústí - Tábor.

3 Poděkování za pomoc při výzkumech zaniklé vsi Hynkovic patři PhDr. Jiřímu Doleželovi z Archeologického ústavu AV ČR, Brno, v. v. i., a Mgr. Blance Mikulkové z Ústavu archeologické památkové péče Brno, v. v. i. Za poskytnutí cenných informací a písemných materiálů děkujeme Ing. Josefu Černohousovi - starostovi obce Jamné nad Orlicí, paní Haně Moravcové - obecní kronikářce, panu Aloisu Sršňovi - bývalému kronikáři obce, panu Mojmíru Malému - bývalému hajnému v Hynkovicích, paní Gabriele Doleželové, panu Václavu Režnému, panu Josefu Filipovi (u Gustů) a dalším nejmenovaným pamětníkům. 
MĚCHUROVÁ, Z., 1980: Podrobná terminologie koňského postroje a jeho částí ve středohradištním období, VVM XXXII, 187-193.

- 1984: Součásti uzdění koně ve velkomoravském období - Die Bestandteile der Reitpferdzäumung in der mittleren Burgwallzeit, AH 9, 263-292.

- 1997: Konůvky - zaniklá středověká ve Ždánickém lese. Studie Archeologického ústavu Akademie věd ČR v Brně XVII/1. Brno.

MUSIL, F., 2002: Osídlování Podorlicka v době předhusitské. Kraj na Tiché Orlici v povodí Třebovky a Moravské Sázavy. Ústí nad Orlicí.

NADOLSKI, A., 1954: Studia nad uzbrojeniem polskim w X, XI i XII wieku. Łódź.

NEKUDA, V., 1975: Pfaffenschlag. Zaniklá středověká ves u Slavonic. Brno.

- 1985: Mstěnice. Zaniklá středověká ves u Hrotovic 1. Hrádek - tvrz - dvůr - předsunutá opevnění. Brno.

RICHTER, M., 1961: K počátkům tak zvaných gotických klíčů - Über den Beginn der sog. gotischen Schlüssel. In: Sborník Československé společnosti archeologické při ČSAV 1. K poctě akademika Jana Eisnera, 96-101. Brno.

- 1982: Hradišt'ko u Davle. Městečko ostrovského kláštera. Praha.

RUTTKAY, A., 1976: Waffen und Reiterausrüstung des 9. bis zur ersten Hälfte des 14. Jahrhunderts in der Slowakei II, SlArch XXIV, 245-395.

SLIVKA, M., 1981: Stredoveké hutníctvo s kováčstvo na východnom Slovensku 3, Historica Carpatica XII, 211-276.

VÍCH, D., 2010: Neznámá vrcholně středověká fortifikace na k. ú. Lanšperk, CB 12, 319-343.

- 2016: Hrádek v Hrádníkách u Zářecké Lhoty na Choceňsku - Eine Burg in Hrádníky bei Zářecká Lhota in der Region Choceň, AH 41, 133-166.

- 2016a: Relikt dřevěné stavby z počátku 14. století v Litomyšli, AVČ 9, 205-222.

ZIMMERMANN, B., 2000: Mittelalterliche Geschossspitzen. Kulturhistorische, archäologische und archäometallurgische Untersuchungen. Basel.

ŽÁKOVSKÝ, P., 2014: Tesáky a problematika jednosečných zbraní středověku a raného novověku. Nepublikovaná disertační práce, Ústav archeologie a muzeologie, FF MU, Brno.

ŽÁKOVSKÝ, P.-HOŠEK, J., 2015: Kovové artefakty. In: Veselí nad Moravou. Středověký hrad v řiční nivě (Plaček, M.-Dejmal, M., edd.), 220-251. Brno.

\section{Zusammenfassung}

\section{Hynkovice - eine unbekannte Dorfwüstung im Adlergebirge}

Im Jahr 2009 wurde an der Grenze des Katastergebietes zwischen Jamné nad Orlicí und Těchonín (Bezirk Ústí nad Orlicí, Landkreis Pardubice, Tschechische Republik) im Adlergebirge eine bisher unbekannte mittelalterliche Dorfwüstung entdeckt.

Die Relikte der einzelnen Anwesen des Dorfes wurden in einem Wiesental und im Waldgelände oberhalb des Baches Černovický potok am Fuß des Berges Javorně (781 ü.d.M.) in einer Höhe von ungefähr 670 m entdeckt. Mit seinem südlichen Teil liegt das Dorf im Katastergebiet von Těchonín (Abb. 1), der östliche Teil reicht bis ins Katastergebiet von Jamné nad Orlicí hinein. Von den Überresten der Dorfwüstung hat einer der Verfasser des vorliegenden Beitrags neun Relikte identifiziert, die mit der Arbeitsbezeichnung Anwesen belegt wurden und $60-80 \mathrm{~m}$ voneinander entfernt liegen (Abb. 2, 3). In dem unruhigen Gelände alter Baumbrüche konnten die einzelnen Anwesen anhand von Mikroritzen identifiziert werden, durch welche bewegliche archäologische Funde zutage gefördert wurden (Abb. 4).

In den Jahren 2011-2012 erfolgten einige individuelle Richtuntersuchungen mit Metalldetektoren. Die Hauptuntersuchung mitttels Detektor erfolgte am 26. 4. 2014 nachdem die finanziellen Mittel für eine geodätische Vermessung der Funde bereitgestellt worden waren (Abb. 5).

In den schriftlichen Quellen vermissen wir jegliche Nachrichten über die Fundstelle. Ausschließlich mündliche Berichte, die erst in der Chronik von Jamné nad Orlicí aus dem Jahr 1926 schriftlich festgehalten wurden, liefern Informationen über die mittelalterliche Dorfwüstung.

Die Gemeinden Těchonín und Jamné nad Orlicí, in deren Katastergebieten sich Hynkovice heute befindet, kommen zuverlässig erstmals im Jahr 1514 (Těchonín) und 1409 (Jamné nad 
Orlicí) in den schriftlichen Quellen vor, wobei vorerst eine noch ungeklärte Frage bleibt, ob beide Gemeinden nicht ältere Vorgänger hatten, die unter den Bezeichnungen Ludmirsdorf und Perchtolsdorf bereits zum Jahr 1304 belegt sind.

Von den neun als Anwesen bezeichneten Situationen handelt es sich bei sechs Situationen mit hoher Wahrscheinlichkeit um Anwesen (Anwesen 1-6), in einem Fall ist ein Anwesen wahrscheinlich (Anwesen 7, Abb. 6), in zwei Fällen geht es um eine Arbeitsbezeichnung der Situationen, bei denen es sich wahrscheinlich um wirtschaftliches Hinterland handelt (sog. Anwesen 8-9).

Als Flurland kann vor allem der Bereich der heutigen Wiese am Forsthaus angesehen werden. Außerhalb davon haben wir im Waldraum nordöstlich vom Forsthaus in der Lage Kopaniny torsohafte Spuren von Grenzstreifen mit aneinandergereihten Steinhaufen entdeckt. Von dort aus ziehen sich Spuren von Feldern in Richtung der Wiese Kováŕka (Abb. 7).

An beweglichen Funden verfügen wir über 266 Bruchstücke hochmittelalterlicher Keramik und 12 Stücke neuzeitlicher Keramik (Abb. 8-9). Einige Bruchstücke verweisen noch mit ihrer technologischen Bearbeitung auf die Tradition des 13. Jahrhunderts, die Anwendung dieser technologischen Tradition an den Kragenrändern verweist uns jedoch ganz an das Ende dieses Jahrhunderts bzw. eher an den Anfang des anschließenden Jahrhunderts. Ins 14. Jahrhundert kann dann die meiste Keramik aus Hynkovice datiert werden. Offen bleibt die Frage wann die Fundstelle wüst wurde. Anhand einiger Merkmale wurde sie im fortgeschrittenen 14. oder im älteren Abschnitt des 15. Jahrhunderts wüst. Keramikware des hochentwickelten 15. Jahrhunderts fehlt bereits in dem Fundkomplex.

Von der Fundstelle stehen uns heute Dank der Detektorprospektion um die 70 Eisengegenstände, ein aus einer Kupferlegierung bestehender Ring und zwei Silbermünzen zur Verfügung. Landwirtschaftliche Geräte sind lediglich als Sichelfragmente vertreten (Auswahl auf Abb. 10:1-6). An Werkzeugen verfügen wir über einen kleinen Hammer (Abb. 11:6) und einen Stangenbohrer (Abb. 11:4). Interessant ist der Fund eines Gegenstandes in Form einer Eisenrute mit einem schaufelförmigen Ende wie es einem Löffelbohrer entspricht (Abb. 11:5). Diesen Gegenständen begegnen wir jedoch lediglich in den deutlich älteren Kontexten. An der Grenze zwischen landwirtschaftlichem Gerät, Werkzeug und Gegenständen des persönlichen Bedarfs stehen Federscheren, die in Hynkovice durch zwei Torsi belegt sind (Abb. 11:1-2). Bei einem spitzen Artefakt handelt es sich um einen Pfriem (Abb. 11:3). Von der Ausrüstung für Pferd und Reiter sind Hufeisenfragmente, ein Teil eines Zaumzeugs, eines Steigbügels und das Bügelfragment eines Sporns erhalten geblieben (Abb. 12). Der Fundkomplex wird ergänzt um Baubeschläge (Abb. 13), Militaria, Gegenstände des persönlichen Bedarfs (Abb. 14, 15:1-3) und um unbestimmte Artefakte (Abb. 15:4-11). Wichtig sind zwei Prager Groschen von Wenzel II. aus den Objekten 5 und 6 (Abb. 16-17). Vom räumlichem Gesichtspunkt aus ist wohl nur die Anhäufung von Sicheln erwähnenswert (Abb. 18).

Das in der mündlichen Überlieferung als Hynkovice bezeichnete Dorf unbekannten Namens ist irgendwann Ende des 13. Jahrhunderts oder direkt zu Beginn des anschließenden Jahrhunderts am Bach Černovický potok entstanden. Zu einer Dorfwüstung wurde es im fortgeschrittenen 14. oder im älteren Abschnitt des 15. Jahrhunderts.

Den Grund dafür, warum Hynkovice in der relativ extremen Lage gegründet wurde, kennen wir nicht (mutmaßliche Bergbauaktivitäten konnten durch die Funde bislang nicht zuverlässig belegt werden), ebenso unbekannt sind uns die Ursachen dafür, dass das Dorf friedlich verlassen wurde. Die einzelnen Anwesen wurden aus Holz gebaut, Steine hatten die Bewohner nur in speziellen Fällen verwendet (kuppelförmige Gebilde, die als Überreste von zerstörten Öfen interpretiert werden). Über das Aussehen der einzelnen Anwesen und weiterer Begleitbauten können wir ohne archäologische Grabung nichts sagen. Die heutige Form der Relikte wurde dann deutlich von Postablagerungsprozessen beeinflusst.

Durch die an der Grenze der Katastergebiete von Těchonín und Jamné nad Orlicí durchgeführte Untersuchung der mittelalterlichen Dorfwüstung konnten zwar nicht die Anfänge dieser Gemeinden deutlich gemacht werden, jedoch hat sie klare Belege dafür geliefert, dass selbst 
bei der nicht eindeutigen Aussage der schriftlichen Quellen zu Beginn des 14. Jahrhunderts am Oberlauf der Stillen Adler mit der Präsenz des Menschen tatsächlich gerechnet werden muss und dass zu dieser Zeit dort auch ein entsprechendes Wegenetz entstanden war.

Der vorliegende Beitrag wurde im Rahmen des Förderprogramms Angewandte Forschung und Entwicklung der nationalen und kulturellen Identität (NAKI II) Nr. DG16P02R031 (Mährische Kreuzungen) ausgearbeitet.

Mojmír Režný, Na Hraničkách 21, 68201 Vyškov, Česká republika

PhDr. David Vích, Regionální muzeum ve Vysokém Mýtě, Šemberova 125, 56601 Vysoké Mýto, Česká republika,dvich@centrum.cz 
